\title{
The Performance of Actively and Passively Managed Swiss Equity Funds
}

\author{
Manuel Ammann and Michael Steiner*
}

JEL-Classification: G11, G12, G14

Keywords: Mutual Funds, Index Funds, Performance, Switzerland

\section{Introduction}

The analysis of the performance of actively managed mutual funds is a widely researched topic. The general finding is that, on average, active mutual funds underperform their benchmarks. Therefore passive investment strategies are advocated. However, most of the existing studies measure the performance in comparison to a theoretical benchmark index. As passive investing is not cost-free, the performance of actively managed mutual funds should be directly compared to passively managed funds.

We provide a comparison of active and passive equity mutual funds using Swiss data. Specifically, we study the performance of 160 mutual funds investing in Swiss stocks from January 1989 to March 2007 using a Switzerland-specific Carhart (1997) model.

Our contribution to the existing literature is threefold:

1. We directly compare actively and passively managed Swiss equity funds. Thereby, we apply a methodology based on the Switzerland-specific CARHART (1997) model provided by AMMAnN and STEINER (2008). To the best of our

* Manuel Ammann (University of St. Gallen, Rosenbergstrasse 52, CH-9000 St.Gallen, manuel. ammann@unisg.ch, +41 7122470 80) is Professor of Finance at the University of St. Gallen. Michael Steiner (Wegelin \& Co. Privatbankiers, Bohl 17, CH-9004 St.Gallen, michael. steiner@wegelin.ch, +41 712425829$)$ is a doctoral candidate at the University of St.Gallen and works for Wegelin \& Co. Private Bankers.

The authors are grateful to Hanspeter Wohlwend, Vadim Safranov, Jan Martin Rous, Sven Wiedmer, Michael Frei, the participants of the "Topics in Finance" seminar at the University of St.Gallen, and the anonymous referees for their valuable comments. 
knowledge, this is the first time active and passive funds are directly compared based on a CARHART (1997) model.

2. We analyse the performance of passive Swiss equity funds.

3. We substantially extend the Swiss studies of Lhabitant (2001), von Wyss (2001), Lhabitant (1995), and Zimmermann and Zogg-Wetter (1992) by applying an advanced performance measurement methodology, by analysing a much larger sample with a reduced survivorship bias, by including the years 2000 to 2007, by analysing factor loadings, and by checking the robustness of the results in subgroups and subperiods of the sample.

The debate on whether active investing is better than indexing has gained in intensity in the last years. MALKIEL (1995) looks at the returns of US mutual funds from 1971 to 1991 and compares them to two benchmarks, the Wilshire 5000 Index and the S\&P 500 Index. He finds that indexing outperforms actively managed funds. Jensen (1968), Lehmann and Modest (1987), Elton, Gruber, and Blake (1996), Gruber (1996), Carhart (1997), Wermers (2000), Malkiel (2003), Deaves (2004), Bogle (2005), Malkiel (2005) and Costa, Jakob, and Porter (2006) find that, on average, actively managed investment funds underperform their benchmarks between 80 and 320 basis points per annum on a risk-adjusted basis.

All of the previously mentioned studies compare actively managed funds to theoretical indices. BOGLE (1998) started a new way of comparing active and passive investing. He compares the performance of US equity investment funds to the performance of Standard \& Poor's index funds from 1992 through 1997. He concludes that the average return for all the funds in the index group is 1.4 percentage points above the average return for the actively managed funds. MinOr (2001) moves the five-year data series from BogLe (1998) two years backwards (1990 through 1994) and finds that actively managed funds outperformed their peers during this period of time. BogLe (2002) responds by analysing a ten-year period from 1991 to 2001. He shows that indexing delivers on average a higher average return. Fortin and Michelson (2002) also find that index funds outperform actively managed funds on average. However, MiNOR (2003) counters by showing that results are not as clear-cut. For a twenty-year period ending December 2001, he concludes that actively managed US funds have essentially the same net-of-fees return as a comparable index fund, with small-cap funds performing better than large-cap funds. ReINKer and Tower (2004) find that it is the time span of the observed returns that determines which instrument delivers superior returns. However, over the whole period actively managed funds outperform their passive peers. Kizer (2004) extends Reinker and Tower's (2004) study 
and finds that the difference in the returns of the active and index portfolios is attributable largely to the value and size premiums.

All the cited studies rely on data of US equity funds. There are few studies analysing the fund universe in Europe. Bams and ОттеN (2002) give a comprehensive overview on earlier European research on mutual fund performance and provide results on France, Germany, Italy, Netherlands and UK from 19911998. The study, based on the Carhart (1997) model, shows that on average the analysed actively managed funds outperform the respective index. GRIESE and KempF (2003) provide a study for German equity mutual funds. For the period from 1980 to 2000 they find that index funds significantly outperform actively managed funds.

In Switzerland, equity mutual fund performance analysis starts with a contribution by Zimmermann and ZogG-Wetter (1992). They analyse the performance of six Swiss equity funds during the time period from 1984 to 1990. They conclude that there is no systematic outperformance of actively managed funds. Lhabitant (1995) continues by analysing the Sharpe- and Treynor-ratios of 17 Swiss equity mutual funds from July 1983 to June 1994. He observes that, on average, the funds fail to beat the market index. Von Wyss (2001) analyses 24 Swiss equity mutual funds from 1995 to 1999, based on a single (market-)factor model and various ratios. $75 \%$ of the alphas in his study are negative, with no significantly positive alpha. Finally, Lhabitant (2001) analyses 60 funds from 1977 to 1999 . He finds an average, not statistically significant Jensen alpha of $-1.78 \%$ p.a. Looking at individual funds, not one out of the nine positive alphas is significant. ${ }^{1}$

Overall, the studies present evidence that actively managed funds are not able to systematically deliver a better performance than their corresponding benchmarks. However, a few studies argue that this result may not be robust.

The remainder of the paper is structured as follows: Section 2 describes our data and Section 3 explains the methodology applied. In Section 4 the results of the empirical study are presented. Section 5 summarizes our key findings.

1 Ammann, HäLler and von Wyss (2002) analyse the performance of six Swiss investment foundations in relation to the benchmarks. The main conclusion of their work is that during the time period from 1996 to 2002 the six analysed foundations do not achieve statistically significant out-/underperformance compared to the benchmark. 


\section{Data}

To study the performance of Swiss equity mutual funds we construct a database consisting of the monthly total returns of 160 mutual funds from 55 firms exclusively investing in Swiss equities. ${ }^{2}$ The end-of-month data available covers the time period from January 1989 to March 2007. The continuously compounded total return data is calculated in Swiss Francs and on a NAV basis. ${ }^{3}$ Overall, the database consists of 13,672 monthly return observations, giving approximately 85 observations (7 years and 1 month) per fund on average. As there exists no complete register where data from Swiss funds are listed, we used the following sources: Swiss Exchange, Swiss Funds Association, Swiss Federal Banking Commission, Swiss Association of Investment Companies, Feri Rating \& Research GmbH, Micropal, Lipper, Bloomberg, Datastream, and Morningstar. Our database does not have information on fund expenses, fund size, or fund holdings as those are only partly or not available at all and because their influence on performance is analysed in earlier studies. The categorization of the funds into active and passive funds, into retail and institutional funds, into SPI-, SMI- and Small\&Mid-Cap-funds, and into surviving and non-surviving funds is described in Table 1. This categorization is strictly based on the information provided by the fund management. Funds are categorized as non-surviving when no performance-data is provided anymore. As our research showed, all 24 nonsurviving funds have either been liquidated or merged. Further, Table 2 presents the number of funds in the database at the end of each calendar year. This table shows that in the early years of the study the number of passive funds is small. The increase of mutual funds in our database reflects the development in Switzerland quite realistically: As published by the Swiss Federal Banking Commission (SFBC), the number of funds in Switzerland increased by factor 8.6 from 1992 to 2007 , whereas our database increased by factor 9 in the same time. ${ }^{4}$

Concerning the classification by benchmark, funds with similar benchmarks have been aggregated into one group based on the correlations of the benchmarks:

2 ETFs (Exchange traded funds) are included. As we have less than 3 funds per firm on average, the database is too fragmented to perform provider-specific analyses.

3 Dividends are assumed to be reinvested. Load charges and redemption fees (if any) are ignored. We have calculated the dividend-adjusted prices for 55 funds. A small bias could be induced by a different fiscal treatment of funds reinvesting the dividends and funds not paying dividends. However, this bias is small and is therefore not taken into account.

4 The comparison with 1992 is chosen as the SFBC makes available these number back to 1992 only. As the data from the SFBC shows, the total number of funds in Switzerland increased from 671 in 1992 to 5794 in 2007. 
Table 1: Breakup of the Funds Analysed by Benchmark, Client Segment, Activity, and Survival

\begin{tabular}{|c|c|c|c|c|c|c|c|c|}
\hline $\begin{array}{l}\text { Fund } \\
\text { benchmark }\end{array}$ & $\begin{array}{l}\text { Fund } \\
\text { category }\end{array}$ & $\begin{array}{r}\text { A } \\
\text { Surviving } \\
\end{array}$ & $\begin{array}{c}\text { tive funds } \\
\text { Non- } \\
\text { surviving }\end{array}$ & Total & $\begin{array}{r}\mathrm{Pa} \\
\text { Surviving }\end{array}$ & $\begin{array}{c}\text { ssive funds } \\
\text { Non- } \\
\text { surviving }\end{array}$ & Total & Total \\
\hline SPI & $\begin{array}{l}\text { Retail } \\
\text { Institutional } \\
\text { Total }\end{array}$ & $\begin{array}{r}49 \\
7 \\
56\end{array}$ & $\begin{array}{l}5 \\
3 \\
8\end{array}$ & $\begin{array}{l}54 \\
10 \\
64\end{array}$ & $\begin{array}{l}3 \\
4 \\
7\end{array}$ & $\begin{array}{l}0 \\
0 \\
0\end{array}$ & $\begin{array}{l}3 \\
4 \\
7\end{array}$ & $\begin{array}{l}57 \\
14 \\
71\end{array}$ \\
\hline SMI & $\begin{array}{l}\text { Retail } \\
\text { Institutional } \\
\text { Total }\end{array}$ & $\begin{array}{r}18 \\
6 \\
24\end{array}$ & $\begin{array}{l}6 \\
3 \\
9\end{array}$ & $\begin{array}{r}24 \\
9 \\
33\end{array}$ & $\begin{array}{r}7 \\
3 \\
10\end{array}$ & $\begin{array}{l}0 \\
1 \\
1\end{array}$ & $\begin{array}{r}7 \\
4 \\
11\end{array}$ & $\begin{array}{l}31 \\
13 \\
44\end{array}$ \\
\hline $\begin{array}{l}\text { Small\&Mid- } \\
\text { Cap (SMC) }\end{array}$ & $\begin{array}{l}\text { Retail } \\
\text { Institutional } \\
\text { Total }\end{array}$ & $\begin{array}{l}25 \\
13 \\
38\end{array}$ & $\begin{array}{l}6 \\
0 \\
6\end{array}$ & $\begin{array}{l}31 \\
13 \\
44\end{array}$ & $\begin{array}{l}1 \\
0 \\
1\end{array}$ & $\begin{array}{l}0 \\
0 \\
0\end{array}$ & $\begin{array}{l}1 \\
0 \\
1\end{array}$ & $\begin{array}{l}32 \\
13 \\
45\end{array}$ \\
\hline Total & & 118 & 23 & 141 & 18 & 1 & 19 & 160 \\
\hline
\end{tabular}

Table 1 shows a breakup of the mutual funds analysed in this study. The funds have been categorized by their benchmark (SMI, SPI, Small\&Mid-Cap), by their client segment (retail/institutional), by their level of activity (active/passive), and by their survival (surviving/non-surviving).

Table 2: Yearly Number of Analysed Mutual Funds at the End of Each Year

\begin{tabular}{cccc}
\hline Year & $\begin{array}{c}\text { Active } \\
\text { funds }\end{array}$ & $\begin{array}{c}\text { Passive } \\
\text { funds }\end{array}$ & All funds \\
\hline 1989 & 5 & 1 & 6 \\
1990 & 8 & 1 & 9 \\
1991 & 11 & 1 & 12 \\
1992 & 14 & 1 & 15 \\
1993 & 17 & 1 & 18 \\
1994 & 22 & 1 & 23 \\
1995 & 31 & 1 & 32 \\
1996 & 45 & 3 & 48 \\
1997 & 56 & 4 & 60 \\
1998 & 60 & 5 & 65 \\
\hline
\end{tabular}

\begin{tabular}{lccc}
\hline Year & $\begin{array}{c}\text { Active } \\
\text { funds }\end{array}$ & $\begin{array}{c}\text { Passive } \\
\text { funds }\end{array}$ & All funds \\
\hline 1999 & 72 & 6 & 78 \\
2000 & 82 & 8 & 90 \\
2001 & 101 & 10 & 111 \\
2002 & 103 & 10 & 113 \\
2003 & 106 & 14 & 120 \\
2004 & 119 & 17 & 136 \\
2005 & 124 & 19 & 143 \\
2006 & 119 & 18 & 137 \\
2007 & 118 & 17 & 135 \\
\hline
\end{tabular}

Table 2 shows the number of Swiss equity mutual funds of this study at the end (December) of each respective year. The classification into active and passive is based on the declaration by the fund manager. 
Funds that report the SPI or the UBS 100 index as their benchmark are allocated to the group "SPI-funds", funds using the SMI or the MSCI Switzerland as their benchmark are allocated to the "SMI-funds" and those reporting Swiss small- and mid-cap stocks as their investment universe are allocated to the "Small\&MidCap-funds". Tests not reported here confirm the classification of the funds.

\section{Methodology}

This section explains how the fund database is analysed. As we have no information on portfolio holdings, we estimate the performance of the funds using the Carhart (1997) regression model. As the Carhart factors are country-specific, Ammann and Steiner (2008) develop the factor premiums for the Switzerlandspecific Carhart model. We apply their Switzerland-specific four-factor model to estimate the performance of the Swiss equity mutual funds. ${ }^{6}$ Formally, this model is estimated as:

$$
R_{i t}-R_{f t}=\alpha_{i T}+\beta_{l i T} R M R F_{t}+\beta_{2 i T} S M B_{t}+\beta_{3 i T} H M L_{t}+\beta_{4 i T} U M D_{t}+e_{i t}
$$

where $R_{i t}-R_{f t}$ is the excess return of mutual fund $i$ over the risk-free rate (CHF call money rate provided by Factset) at time t. $R M R F_{t}$ is the excess return of the benchmark portfolio over the risk-free rate at time $t$ and $S M B_{t}, H M L_{t}$, and $U M D_{t}$ are the returns of zero-investment factor-mimicking portfolios for size, value, and momentum at time $t$. Finally, the intercept $\alpha_{i}$ is our performance measure, estimating the fund performance relative to the four-factor benchmark. Time series for the Switzerland-specific SMB, HML, and UMD factor premiums are provided by Ammann and Steiner (2008). They describe in detail the construction, characteristics, and robustness of these factors.

By means of panel regressions, this four-factor measurement methodology is applied to all performance evaluations in this paper. In a first step, the benchmark portfolio is an index. The performance of passive and active funds in various subgroups and during different subperiods is evaluated against this theoretical benchmark portfolio. Table 3 gives the definitions of the subgroups and subperiods analysed. In a second step, actively managed funds are tested against

5 Tracking errors and correlations in comparison to the appropriate benchmark indices confirm the validity of the classification of the funds.

6 All details concerning the CARHART (1997) regression model and the construction of the factors $\mathrm{SMB}_{\mathrm{t}}, \mathrm{HML}_{\mathrm{t}}$, and $\mathrm{UMD}_{\mathrm{t}}$ are provided by Ammann and STEiner (2008). 
Table 3: Definitions of the Subgroups and Subperiods Analysed

\begin{tabular}{|c|c|c|}
\hline $\begin{array}{l}\text { Panel 1: Subgroups } \\
\text { Classification } \\
\text { criterion }\end{array}$ & Subgroup name & Definition \\
\hline None & All funds & All 160 active and passive funds. \\
\hline \multirow{2}{*}{ Activity } & Active funds & $\begin{array}{l}\text { All funds with an active investment strategy. Overall, } \\
\text { there are } 141 \text { active funds. }\end{array}$ \\
\hline & Passive funds & $\begin{array}{l}\text { All funds with a passive investment strategy. Overall, } \\
\text { there are } 19 \text { passive funds. }\end{array}$ \\
\hline \multirow{2}{*}{ Client segment } & Retail funds & $\begin{array}{l}\text { All funds that are distributed with a focus on retail } \\
\text { investors. Overall, there are } 120 \text { retail funds. }\end{array}$ \\
\hline & Institutional funds & $\begin{array}{l}\text { All funds that are distributed to institutional investors } \\
\text { only. Overall, there are } 40 \text { institutional funds. }\end{array}$ \\
\hline \multirow{2}{*}{ Survival } & Surviving funds & $\begin{array}{l}\text { All funds that still existed at the end of the observation } \\
\text { period (March 2007). Overall, there are } 136 \text { surviving } \\
\text { funds. }\end{array}$ \\
\hline & $\begin{array}{l}\text { Non-surviving } \\
\text { funds }\end{array}$ & $\begin{array}{l}\text { All funds that were liquidated or merged before the end } \\
\text { of the observation period (March 2007). Overall, there } \\
\text { are } 24 \text { non-surviving funds. }\end{array}$ \\
\hline \multirow{3}{*}{$\begin{array}{l}\text { Investment } \\
\text { universe }\end{array}$} & SPI-funds & $\begin{array}{l}\text { Funds that reported the SPI or the UBS } 100 \text { index as } \\
\text { benchmark. Overall, there are } 71 \text { SPI-funds. }\end{array}$ \\
\hline & SMI-funds & $\begin{array}{l}\text { Funds that reported the SMI or the MSCI Switzerland } \\
\text { as benchmark. Overall, there are } 44 \text { SMI-funds. }\end{array}$ \\
\hline & $\begin{array}{l}\text { Small \&Mid-Cap- } \\
\text { funds (SMC-funds) }\end{array}$ & $\begin{array}{l}\text { Funds that focus their investments on Small- and Mid- } \\
\text { Cap stocks only. Overall, there are } 45 \text { SMC-funds. }\end{array}$ \\
\hline
\end{tabular}

\begin{tabular}{|c|c|c|}
\hline $\begin{array}{l}\text { Panel 2: Subpe } \\
\text { Classification } \\
\text { criterion }\end{array}$ & Subperiod name & Definition \\
\hline None & Whole period & All observations (January 1989-March 2007). \\
\hline \multirow{2}{*}{ Century } & Early & $\begin{array}{l}\text { All observations before the millenium (January } \\
\text { 1989-December 1999). }\end{array}$ \\
\hline & Late & $\begin{array}{l}\text { All observations after the millenium (January 2000- } \\
\text { March 2007). }\end{array}$ \\
\hline \multirow{2}{*}{$\begin{array}{l}\text { Stock market } \\
\text { condition }\end{array}$} & Bear & $\begin{array}{l}\text { All observations during the bear market from Septem- } \\
\text { ber 2000-March } 2003 \text {. }\end{array}$ \\
\hline & Bull & $\begin{array}{l}\text { All observations during the bull market from April } \\
\text { 2003-March } 2007 \text {. }\end{array}$ \\
\hline
\end{tabular}

Table 3 defines the subgroups (Panel 1) and subperiods (Panel 2) analysed. In the paper, combinations of these subgroups and subperiods are studied as well. The categorization is strictly based on the declaration made by the management of the funds. 
equally weighted benchmark portfolios constructed from the passively managed funds in our database. The benchmark portfolio is therefore an investable portfolio of tradable passive funds. Again, various subgroups during different subperiods are analysed. The alphas resulting from these panel regressions are a direct estimate of how the actively managed Swiss equity mutual funds performed in comparison to their passively managed peers. In a third step, SPI-, SMI-, and Small\&Mid-Cap-Funds are analysed separately against corresponding equally weighted benchmark portfolios of passive funds. The robustness of the results is tested in different subgroups and during different subperiods.

As several studies have shown before, a survivorship bias could potentially influence the results. If the records of non-surviving funds - most probably the worst performing ones - were not included, a potential study could only take into account the slightly higher performance of the surviving funds. Such a study would suffer from a survivorship bias and not reflect the true picture of the average fund performance. The survivorship bias is well documented for US equities. Grinblatt and Titman (1989) find a survivorship bias between 10 and 30 basis points on a yearly basis (data from 1975 to 1984). Brown and GoETZMANN (1995) find a bias of around 20 to 80 basis points per year (data from 1976 to 1988). The survivorship bias in Malkiel (1995), Elton, Gruber, and Blake (1996), Gruber (1996) and Carhart, Carpenter, Lynch, and Musto (2002) ranges from $0.07 \%$ to $2.1 \%$ per annum, dependent on the calculation method and weighting scheme used.

Table 4 gives an estimate of the survivorship bias based on our Switzerlandspecific data. These numbers are in line with the literature described above. By taking the performance of non-surviving funds into account, our analysis is not affected substantially by the survivorship bias. ${ }^{7}$ This is an improvement over earlier Swiss studies, where a possible survivorship bias is not accounted for.

7 As we cannot exclude the possibility of the existence of more non-surviving funds than included in our data, we may not completely rule out a survivorship bias. 
Table 4: Estimation of the Survivorship Bias for the Active Funds in the Database

\begin{tabular}{lcc}
\hline & \multicolumn{2}{c}{$\Delta$ Alpha (annualized) } \\
Calculation method & $1 / 1989-$ & $1 / 2000-$ \\
$3 / 2007$ & $3 / 2007$ \\
\hline Alpha surviving active funds - alpha all active funds & $0.07 \%$ & $0.34 \%$ \\
Alpha surviving active funds - alpha non-surviving active funds & $0.52 \%$ & $2.40 \%$ \\
\hline
\end{tabular}

Table 4 shows an estimation of the survivorship bias based on our database. Two measures that estimate the bias are calculated for all active funds in the database. The first is the difference of the annualized alphas of the surviving funds and all (surviving/non-surviving) funds, the second is the difference of the annualized alphas of the surviving funds and the non-surviving funds. These $\Delta$ alphas are calculated for two different time periods (January 1989-March 2007; January 2000-March 2007). All alphas are calculated with panel regressions based on the Switzerlandspecific Carhart (1997) model presented by Ammann and Steiner (2008). The benchmark portfolio is the benchmark-equivalent portfolio of passive funds.

\section{Empirical Results}

This section studies the performance of the funds using the Switzerland-specific Carhart model of Ammann and Steiner (2008). We start with aggregated samples in comparison to the index and proceed by breaking it down into more detail and by performing comparisons to passive funds. For the regressions, we always use the corresponding index or passive funds as benchmark portfolio, meaning that we compare SPI-funds to the SPI or passive SPI-funds, SMIfunds to the SMI or passive SMI-funds, and SMC-funds to the SMIM or passive SMIM-funds.

The first part (Tables 5 to 13) measures the performance against corresponding indices. Tables 5 and 6 start with an aggregate overview. Tables 7 to 9 (Section 4.1) analyse the performance of passive funds compared to their reference index. Tables 10 and 11 (Section 4.2) measure the performance of active management in comparison to the corresponding index. Tables 12 and 13 (Section 4.3) complete the first part by showing the distribution of the alphas (in comparison to corresponding indices) and the factor loadings of the regressions for all 160 single funds. The second part (Tables 14 to 17) measures the performance of the active funds in comparison to the passive funds. Tables 14 and 15 (Section 4.4) give an aggregated overview. Section 4.5 looks at more detail: Table 16 analyses the performance of the active SPI- and Table 17 of the active SMI-funds in comparison to their passive counterpart. 
Table 5 allows first conclusions. Comparing all funds during the whole period to their corresponding index, we find a significant underperformance of $-0.4 \%$ p.a. on the highest aggregated basis. All active funds show an underperformance of $-0.4 \%$ p.a. as well, with significance at the $10 \%$-level. All passive funds underperform their corresponding index by a highly significant $-0.8 \%$ p.a.

Further, Table 5 shows the factor loadings of the regressions. As expected from a theoretical point of view, we find significant loadings for the active funds, but no loadings significantly different from the expected value for the passive funds. Overall, the active funds show a highly significant, positive loading for the size factor and a highly significant, negative loading for the momentum factor. The value factor has a positive loading, significant at the $10 \%$ level. These factor loadings show that, on average, managers of active Swiss equity funds systematically overweight small-cap, value, and low-momentum stocks in comparison to their benchmark. Further, the significant difference of the market beta of active funds from 1 indicates that, on average, the funds are either holding low-beta stocks or are not fully invested in equities but hold a strategic proportion of cash.

Table 6 breaks these results down into subperiods. We find that the performance of the active funds is better in the "Early" than in the "Late" time period. ${ }^{8}$ A possible interpretation could be that financial markets became more efficient during the last 18 years. Consequently, active funds had increasing difficulties to perform well. The performance of passive funds remains stable during these two periods. However, results for passive funds during the "Early" period have to be interpreted with care as the number of passive funds is small during that period.

Further, Table 6 indicates that active and passive funds perform better during the "Bear" market than during the "Bull" market. Thus, market direction seems to influence the risk-adjusted performance of fund managers. This observation is in line with the findings of COSTA, ЈАков, and PORTeR (2006) for US funds.

Finally, the last column of Table 6 shows the differences between the alphas of the subgroup of all active and all passive funds and its significance. ${ }^{9}$ All differences are in favour of the active funds, but none are significant. Thus, no conclusion is possible whether active or passive investing actually performs better.

In sum, Tables 5 and 6 show five important findings. First, we observe a significant underperformance of active and passive funds in comparison to their corresponding index ("Observation One"). Second, no conclusion on the superiority

8 The subgroups and subperiods are described in Table 4.

9 In this paper, the significance of differences of alphas is tested by means of a t-test. 
Table 5: Annualized Performance of the Funds and Regression Factor Loadings

\begin{tabular}{llccc}
\hline & & \multicolumn{3}{c}{ Subgroup } \\
& & All funds & Active funds & Passive funds \\
\hline \multirow{3}{*}{ Whole period } & Alpha & $-0.4 \%^{* *}$ & $-0.4 \%^{*}$ & $-0.8 \%^{* * *}$ \\
& t-statistic & -2.02 & -1.77 & -3.54 \\
& Observations & 13,672 & 12,218 & 1,454 \\
& Adj. R-squared & 0.86 & 0.85 & 0.98 \\
Market- $\beta$ & Factor-loading & $0.93^{* * *}$ & $0.92^{* * *}$ & 1.00 \\
\multirow{3}{*}{ Size- $\beta$} & t-statistic (to 1) & -19.87 & -19.88 & 0.78 \\
& Factor-loading & $0.11^{* * *}$ & $0.13^{* * *}$ & 0.00 \\
Value- $\beta$ & t-statistic (to 0) & 17.24 & 17.78 & -0.67 \\
& Factor-loading & $0.01^{*}$ & $0.02^{*}$ & 0.00 \\
\multirow{2}{*}{ Momentum- $\beta$} & t-statistic (to 0) & 1.87 & 1.93 & 0.20 \\
& Factor-loading & $-0.06^{* * *}$ & $-0.07^{* * *}$ & -0.01 \\
& t-statistic (to 0) & -12.44 & -12.30 & -1.08 \\
\hline
\end{tabular}

Table 5 shows the estimation of the performance of the groups of all funds, of all active funds, and of all passive funds compared to their corresponding benchmark index (benchmark portfolio). The performance is measured by the annualized alpha from panel regressions of the Switzerlandspecific Carhart (1997) model. The risk premiums for the size, value, and momentum factors are provided by Ammann and Steiner (2008). The alphas are calculated for the whole time period. In addition to the performance, the alpha's t-statistic, the number of observations, the adjusted $\mathrm{R}$-squared of the regressions, and the factor loadings and their t-statistics are shown. The asterisks indicate significance at the $1 \%$-level $(* * *), 5 \%$-level $\left({ }^{* *}\right)$, and $10 \%$-level $\left({ }^{*}\right)$.

of the performance of active or passive investing may be drawn so far as the difference in the alpha is not significant ("Observation Two"). Third, active funds perform better in the "Early" than in the "Late" time period, which could be due to increased market efficiency. Passive funds, however, show stable performance during the "Early" and the "Late" time period ("Observation Three"). Fourth, active and passive managers perform better in "Bear" markets than in "Bull" markets ("Observation Four"). Fifth, the factor loadings show that on average managers of active Swiss equity funds overweight small-cap, value, and low-momentum stocks in comparison to their benchmark ("Observation Five"). The following sections will validate these observations and test their robustness. 
Table 6: Annualized Performance of the Funds Compared to Their Benchmark Index

\begin{tabular}{|c|c|c|c|c|c|}
\hline Subperiod & & All funds & Active funds & Passive funds & $\begin{array}{c}\text { difference of } \\
\text { alphas } \\
\text { (act. vs. pas.) }\end{array}$ \\
\hline \multirow{4}{*}{ Whole period } & Alpha & $-0.4 \%^{* *}$ & $-0.4 \% *$ & $-0.8 \% \%^{* * *}$ & $0.4 \%$ \\
\hline & t-statistic & -2.02 & -1.77 & -3.54 & 0.55 \\
\hline & Observations & 13,672 & 12,218 & 1,454 & - \\
\hline & Adj. R-squared & 0.86 & 0.85 & 0.98 & - \\
\hline \multirow{4}{*}{ Early } & Alpha & $0.1 \%$ & $0.2 \%$ & $-0.8 \%$ & $1.0 \%$ \\
\hline & t-statistic & 0.12 & 0.32 & -1.46 & 0.60 \\
\hline & Observations & 3,360 & 3,068 & 292 & - \\
\hline & Adj. R-squared & 0.86 & 0.85 & 0.98 & - \\
\hline \multirow{4}{*}{ Late } & Alpha & $-0.5 \%^{* *}$ & $-0.5 \% *$ & $-0.9 \% * * *$ & $0.4 \%$ \\
\hline & t-statistic & -2.08 & -1.91 & -3.62 & 0.51 \\
\hline & Observations & 10,312 & 9,150 & 1,162 & - \\
\hline & Adj. R-squared & 0.85 & 0.84 & 0.98 & - \\
\hline \multirow{4}{*}{ Bear } & Alpha & $0.4 \%$ & $0.5 \%$ & $0.0 \%$ & $0.4 \%$ \\
\hline & t-statistic & 0.72 & 0.69 & 0.04 & 0.20 \\
\hline & Observations & 3,278 & 2,982 & 296 & - \\
\hline & Adj. R-squared & 0.83 & 0.82 & 0.97 & - \\
\hline \multirow{4}{*}{ Bull } & Alpha & $-0.1 \%$ & $-0.1 \%$ & $-0.9 \% \%^{* * *}$ & $0.9 \%$ \\
\hline & t-statistic & -0.54 & -0.22 & -3.71 & 1.13 \\
\hline & Observations & 6,367 & 5,559 & 808 & - \\
\hline & Adj. R-squared & 0.83 & 0.82 & 0.98 & - \\
\hline
\end{tabular}

Table 6 shows the estimation of the performance of the groups of all funds, of all active funds, and of all passive funds compared to their corresponding benchmark index (benchmark portfolio). The performance is measured by the annualized alpha from panel regressions of the Switzerlandspecific Carhart (1997) model. The risk premiums for the size, value, and momentum factors are provided by Ammann and Steiner (2008). The alphas are calculated for different time periods that are described in Table 3. In addition to the performance, the alpha's t-statistic, the number of observations, and the adjusted R-squared of the regressions are shown. The last column of the table shows the differences of the alphas between active and passive funds, testing the significance of these differences by means of a t-test. The asterisks indicate significance at the $1 \%$-level (**), $5 \%$-level $\left({ }^{* *}\right)$, and $10 \%$-level $(*)$. 


\subsection{Passive Funds vs. Index}

Tables 7, 8, and 9 show the results of the performance analysis of various subgroups of passive Swiss equity funds. The performance of the passive funds is measured against their corresponding index.

For all subgroups of passive funds analysed in Tables 7 and 8, "Observation One" (underperformance), "Observation Three" (no evidence for a performance difference during the "Early" and "Late" time period), and "Observation Four" (better performance during "Bear" period than during "Bull" period) from the last paragraph are confirmed. "Observation Two" and "Observation Five" (concerning active funds) cannot be further validated as these tables show results for passive funds only.

As Table 7 shows, both passive SPI- and SMI-funds underperform their corresponding index significantly by $-0.5 \%$ p.a. and $-1.0 \%$ p.a., respectively. We find an underperformance for all subperiods but the "Bear" period where the alphas are close to zero for both subgroups. The same is true for the passive institutional and retail funds in Table 8: Both significantly underperform, with the exception of the "Bear" period. The risk-adjusted performance of the passive Small\&Mid-Cap-Fund is substantially negative as well. However, this result has to be interpreted with care as there is only one fund with just a few observations.

The analysis of the subgroups of the passive SMI-, SPI- and SMC-funds in Table 7 provides one further finding. Passive SPI-funds show a smaller underperformance than passive SMI- or SMC-funds. However, a t-test not reported here shows that this result is not statistically significant.

Table 9 exhibits the performance of passive SMI-ETFs compared to the SMI. The average alpha of the three available ETFs is negative, but not statistically significant. 
Table 7: Annualized Performance of Passive Funds Compared to Their Benchmark Index

\begin{tabular}{|c|c|c|c|c|c|}
\hline \multirow[b]{2}{*}{ Subperiod } & & \multicolumn{4}{|c|}{ Subgroup } \\
\hline & & $\begin{array}{l}\text { All passive } \\
\text { funds }\end{array}$ & $\begin{array}{l}\text { Passive } \\
\text { SPI-funds }\end{array}$ & $\begin{array}{l}\text { Passive } \\
\text { SMI-funds }\end{array}$ & $\begin{array}{c}\text { Passive } \\
\text { SMC-funds }\end{array}$ \\
\hline $\begin{array}{l}\text { Whole } \\
\text { period }\end{array}$ & $\begin{array}{l}\text { Alpha } \\
\text { t-statistic } \\
\text { Observations } \\
\text { Adj. R-squared }\end{array}$ & $\begin{array}{c}-0.8 \%^{* * *} \\
-3.54 \\
1,454 \\
0.98\end{array}$ & $\begin{array}{l}-0.5 \%^{* *} \\
-2.13 \\
597 \\
0.99\end{array}$ & $\begin{array}{l}-1.0 \% \text { \%** } \\
-2.78 \\
830 \\
0.97\end{array}$ & $\begin{array}{l}-2.2 \% \\
-1.64 \\
27 \\
0.99\end{array}$ \\
\hline Early & $\begin{array}{l}\text { Alpha } \\
\text { t-statistic } \\
\text { Observations } \\
\text { Adj. R-squared }\end{array}$ & $\begin{array}{c}-0.8 \% \\
-1.46 \\
292 \\
0.98\end{array}$ & $\begin{array}{c}-0.9 \%^{*} \\
-1.78 \\
176 \\
0.99\end{array}$ & $\begin{array}{c}-0.8 \% \\
-0.72 \\
116 \\
0.98\end{array}$ & $\begin{array}{c}\text { n.a. } \\
- \\
- \\
-\end{array}$ \\
\hline Late & $\begin{array}{l}\text { Alpha } \\
\text { t-statistic } \\
\text { Observations } \\
\text { Adj. R-squared }\end{array}$ & $\begin{array}{c}-0.9 \%^{* * *} \\
-3.62 \\
1,162 \\
0.98\end{array}$ & $\begin{array}{c}-0.4 \% \\
-1.42 \\
421 \\
0.99\end{array}$ & $\begin{array}{c}-1.2 \%^{* * *} \\
-3.08 \\
714 \\
0.97\end{array}$ & $\begin{array}{l}-2.2 \% \\
-1.64 \\
27 \\
0.99\end{array}$ \\
\hline Bear & $\begin{array}{l}\text { Alpha } \\
\text { t-statistic } \\
\text { Observations } \\
\text { Adj. R-squared }\end{array}$ & $\begin{array}{c}0.0 \% \\
0.04 \\
296 \\
0.97\end{array}$ & $\begin{array}{l}0.2 \% \\
0.12 \\
93 \\
0.97\end{array}$ & $\begin{array}{c}0.0 \% \\
0.00 \\
203 \\
0.96\end{array}$ & $\begin{array}{c}\text { n.a. } \\
- \\
- \\
-\end{array}$ \\
\hline Bull & $\begin{array}{l}\text { Alpha } \\
\text { t-statistic } \\
\text { Observations } \\
\text { Adj. R-squared }\end{array}$ & $\begin{array}{l}-0.9 \% \text { \%** } \\
-3.71 \\
808 \\
0.98\end{array}$ & $\begin{array}{l}-0.5 \% \text { \%** } \\
-3.86 \\
307 \\
1.00\end{array}$ & $\begin{array}{l}-1.1 \% \text { *** } \\
-2.60 \\
474 \\
0.96\end{array}$ & $\begin{array}{l}-2.2 \% \\
-1.64 \\
27 \\
0.99\end{array}$ \\
\hline
\end{tabular}

Table 7 shows the estimation of the performance of the groups of all passive funds, of all passive SPI-funds, of all passive SMI-funds, and of all passive SMC-funds (Small\&Mid-Cap-funds) compared to their corresponding benchmark index (benchmark portfolio). The performance is measured by the annualized alpha from panel regressions of the Switzerland-specific Carhart (1997) model. The risk premiums for the size, value, and momentum factors are provided by Ammann and Steiner (2008). The alphas are calculated for different time periods that are described in Table 3. In addition to the performance, the alpha's t-statistic, the number of observations, and the adjusted $\mathrm{R}$-squared of the regressions are shown. The asterisks indicate significance at the $1 \%$-level (***), $5 \%$-level $(* *)$, and $10 \%$-level $(*)$.

$\ddagger$ As there is only one passive fund with just 27 observations, these results for the SMC-funds have to be interpreted with care. 
Table 8: Annualized Performance of Passive Institutional and Retail Funds Compared to Their Benchmark Index

\begin{tabular}{|c|c|c|c|c|}
\hline Subperiod & & $\begin{array}{c}\text { All passive } \\
\text { funds }\end{array}$ & $\begin{array}{c}\text { Subgroup } \\
\text { Passive institu- } \\
\text { tional funds }\end{array}$ & $\begin{array}{c}\text { Passive retail } \\
\text { funds }\end{array}$ \\
\hline $\begin{array}{l}\text { Whole } \\
\text { period }\end{array}$ & $\begin{array}{l}\text { Alpha } \\
\text { t-statistic } \\
\text { Observations } \\
\text { Adj. R-squared }\end{array}$ & $\begin{array}{c}-0.8 \%^{* * *} \\
-3.54 \\
1,454 \\
0.98\end{array}$ & $\begin{array}{l}-0.7 \%^{* *} \\
-2.57 \\
361 \\
0.99\end{array}$ & $\begin{array}{c}-0.8 \% \text { \%** } \\
-2.84 \\
1,093 \\
0.98\end{array}$ \\
\hline Early & $\begin{array}{l}\text { Alpha } \\
\text { t-statistic } \\
\text { Observations } \\
\text { Adj. R-squared }\end{array}$ & $\begin{array}{c}-0.8 \% \\
-1.46 \\
292 \\
0.98\end{array}$ & $\begin{array}{l}-0.1 \% \\
-0.29 \\
12 \\
1.00\end{array}$ & $\begin{array}{c}-0.8 \% \\
-1.44 \\
280 \\
0.98\end{array}$ \\
\hline Late & $\begin{array}{l}\text { Alpha } \\
\text { t-statistic } \\
\text { Observations } \\
\text { Adj. R-squared }\end{array}$ & $\begin{array}{c}-0.9 \%^{* * *} \\
-3.62 \\
1,162 \\
0.98\end{array}$ & $\begin{array}{l}-0.8 \%^{* * *} \\
-2.59 \\
349 \\
0.99\end{array}$ & $\begin{array}{l}-1.0 \%^{* * *} \\
-2.78 \\
813 \\
0.97\end{array}$ \\
\hline Bear & $\begin{array}{l}\text { Alpha } \\
\text { t-statistic } \\
\text { Observations } \\
\text { Adj. R-squared }\end{array}$ & $\begin{array}{c}0.0 \% \\
0.04 \\
296 \\
0.97\end{array}$ & $\begin{array}{l}-1.4 \% \\
-1.44 \\
31 \\
0.99\end{array}$ & $\begin{array}{c}0.2 \% \\
0.22 \\
265 \\
0.96\end{array}$ \\
\hline Bull & $\begin{array}{l}\text { Alpha } \\
\text { t-statistic } \\
\text { Observations } \\
\text { Adj. R-squared }\end{array}$ & $\begin{array}{l}-0.9 \% \text { \%** } \\
-3.71 \\
808 \\
0.98\end{array}$ & $\begin{array}{c}-0.5 \%^{*} \\
-1.66 \\
310 \\
0.98\end{array}$ & $\begin{array}{l}-1.2 \%^{* * *} \\
-3.24 \\
498 \\
0.97\end{array}$ \\
\hline
\end{tabular}

Table 8 shows the estimation of the performance of the groups of all passive funds, of all passive institutional funds, and of all passive retail funds compared to their corresponding benchmark index (benchmark portfolio). The performance is measured by the annualized alpha from panel regressions of the Switzerland-specific Carhart (1997) model. The risk premiums for the size, value, and momentum factors are provided by Ammann and Steiner (2008). The alphas are calculated for different time periods that are described in Table 3. In addition to the performance, the alpha's t-statistic, the number of observations, and the adjusted R-squared of the regressions are shown. The asterisks indicate significance at the $1 \%$-level $(* * *), 5 \%$-level $\left({ }^{* *}\right)$, and $10 \%$-level $\left(^{*}\right)$. The numbers for the institutional funds in the periods "Early" and "Bear" have to be interpreted with care as the samples are small. 
Table 9: Annualized Performance of the ETFs and Regression Factor Loadings Compared to the SMI

\begin{tabular}{llcccc}
\hline & & \multicolumn{4}{c}{ Subgroup } \\
& & All & ETF 1 & $\begin{array}{c}\text { ETF 2 } \\
\text { (on SMI) }\end{array}$ & $\begin{array}{c}\text { ETF 3 } \\
\text { (on SMI) }\end{array}$ \\
\hline \multirow{3}{*}{ Whole period } & Alpha & $-0.3 \%$ & $0.3 \%$ & $0.7 \%$ & $-1.5 \%$ \\
& t-statistic & -0.35 & 0.24 & 0.46 & -0.89 \\
& Observations & 183 & 39 & 72 & 72 \\
Market- $\beta$ & Adj. R-squared & 0.96 & 0.97 & 0.97 & 0.96 \\
(whole) & Factor-loading & $1.04^{*}$ & 0.98 & 0.99 & $1.13^{* * *}$ \\
Size- $\beta$ & t-statistic (to 1) & 1.90 & -0.67 & -0.40 & 3.01 \\
(whole) & Factor-loading & -0.01 & -0.04 & -0.02 & 0.03 \\
Value- $\beta$ & t-statistic (to 0) & -0.21 & -1.03 & -0.48 & 0.48 \\
(whole) & Factor-loading & 0.03 & -0.02 & 0.02 & 0.05 \\
Momentum- $\beta$ & t-statistic (to 0) & 0.87 & -0.37 & 0.43 & 0.88 \\
(whole) & Factor-loading & -0.02 & 0.01 & -0.05 & 0.02 \\
& t-statistic (to 0) & -0.99 & 0.16 & -1.39 & 0.54 \\
\hline
\end{tabular}

Table 9 shows the estimation of the performance of the ETFs to their corresponding benchmark index (benchmark portfolio). The performance is measured by the annualized alpha from panel regressions of the Switzerland-specific Carhart (1997) model. Data for the ETFs is available from April 2001 to March 2007. The risk premiums for the size, value, and momentum factors are provided by Ammann and Steiner (2008). The alphas are calculated for the whole time period. In addition to the performance, the alpha's t-statistic, the number of observations, the adjusted $\mathrm{R}$-squared of the regressions, and the factor loadings and their t-statistics are shown. The asterisks indicate significance at the $1 \%$-level $\left({ }^{* *}\right), 5 \%$-level $\left({ }^{* *}\right)$, and $10 \%$-level $\left({ }^{*}\right)$. 


\subsection{Active Funds vs. Index}

Tables 10 and 11 add further detail and validate the aggregate results for all active funds in Table 6 . The performance of the active funds is measured for various subgroups and during different subperiods.

Table 10 breaks down the performance of all active funds into the groups of all active SPI-, SMI-, and SMC-funds, comparing each group to its corresponding index. While active SPI- and SMI-funds underperform the index by a highly significant $-2.0 \%$ p.a. and $-2.6 \%$ p.a. respectively, the SMC-funds outperform the index by $2.0 \%$ p.a. As Table 10 Panel 2 shows, the alpha of the Small\&Mid-Cap-funds is significantly higher than of SPI- and SMI-funds. These results support the hypothesis that the efficiency in the small- and mid-cap stock segment is substantially lower than in the large-cap segment, allowing positive average alphas of Small\&Mid-Cap-funds.

Another interesting observation from Table 10 is the superiority of the "Early" over the "Late" time period in the segment of SPI- and SMI-funds. "Observation Three" from Table 6 (superior performance of "Early" vs. "Late" time period) is therefore confirmed for large-cap funds. Increasing market efficiency in the large-cap segment could be the reason for this result. The performance of SMCfunds does not substantially change from the "Early" to the "Late" time period. Perhaps the growth of the number of listed Swiss Small\&Mid-Cap-firms from 1998 to $2000^{10}$ lead to additional return opportunities in this segment, compensating the efficiency increase.

Table 10 also shows that the SPI- and SMC-funds perform better in the "Bear" than in "Bull" period, while the SMI-funds perform better in the "Bull" period. Though the Bull-Bear-spread depends on the subgroup analysed. "Observation Four" (superior performance of "Bear" vs. "Bull" time period) from Table 6 is therefore not confirmed by the results.

Finally, Table 11 shows one new finding ("Observation Six"): Active institutional funds perform better than active retail funds during all periods, although the difference is significant for the "Bull" period only. Active institutional funds perform even marginally better than their corresponding index, although not significantly so. Further, Table 11 confirms above findings: "Observation Three" (superior performance of "Early" vs. "Late" time period) gets further support, whereas "Observation Four" (Bull-Bear-spread) is mixed for these two subgroups as well. ${ }^{11}$

10 Source: Yearly Swiss stock guide provided by the FuW.

11 As we analyse no passive funds in this section, no conclusions with respect to "Observation Two" is possible. 
Table 10, Panel 1: Annualized Performance of Active Funds

Compared to their Benchmark Index

\begin{tabular}{|c|c|c|c|c|c|}
\hline \multirow[b]{2}{*}{ Subperiod } & & \multicolumn{4}{|c|}{ Subgroup } \\
\hline & & $\begin{array}{c}\text { All active } \\
\text { funds }\end{array}$ & $\begin{array}{l}\text { Active } \\
\text { SPI-funds }\end{array}$ & $\begin{array}{c}\text { Active } \\
\text { SMI-funds }\end{array}$ & $\begin{array}{c}\text { Active } \\
\text { SMC-funds }\end{array}$ \\
\hline Whole Period & $\begin{array}{l}\text { Alpha } \\
\text { t-statistic } \\
\text { Observatons } \\
\text { Adj. R-squared }\end{array}$ & $\begin{array}{c}-0.4 \%^{*} \\
-1.77 \\
12,218 \\
0.85\end{array}$ & $\begin{array}{c}-2.0 \%^{* * *} \\
-7.62 \\
6,019 \\
0.90\end{array}$ & $\begin{array}{c}-2.6 \% \text { \%** } \\
-4.87 \\
2,846 \\
0.82\end{array}$ & $\begin{array}{c}2.0 \%^{* * *} \\
3.78 \\
3,353 \\
0.83\end{array}$ \\
\hline Early & $\begin{array}{l}\text { Alpha } \\
\text { t-statistic } \\
\text { Observations } \\
\text { Adj. R-squared }\end{array}$ & $\begin{array}{c}0.2 \% \\
0.32 \\
3,068 \\
0.85\end{array}$ & $\begin{array}{c}-0.9 \%^{*} \\
-1.80 \\
1,705 \\
0.91\end{array}$ & $\begin{array}{c}0.0 \% \\
-0.03 \\
607 \\
0.85\end{array}$ & $\begin{array}{c}2.0 \%^{*} \\
1.81 \\
756 \\
0.80\end{array}$ \\
\hline Late & $\begin{array}{l}\text { Alpha } \\
\text { t-statistic } \\
\text { Observations } \\
\text { Adj. R-squared }\end{array}$ & $\begin{array}{c}-0.5 \%^{*} \\
-1.91 \\
9,150 \\
0.84\end{array}$ & $\begin{array}{c}-3.0 \% \text { \%** } \\
-9.54 \\
4,314 \\
0.89\end{array}$ & $\begin{array}{c}-4.3 \% * * * \\
-6.89 \\
2,239 \\
0.81\end{array}$ & $\begin{array}{c}2.4 \%^{* * *} \\
3.87 \\
2,597 \\
0.84\end{array}$ \\
\hline Bear & $\begin{array}{l}\text { Alpha } \\
\text { t-statistic } \\
\text { Observations } \\
\text { Adj. R-squared }\end{array}$ & $\begin{array}{c}0.5 \% \\
0.69 \\
2,982 \\
0.82\end{array}$ & $\begin{array}{c}-0.6 \% \\
-0.87 \\
1,363 \\
0.88\end{array}$ & $\begin{array}{c}-2.7 \% * * \\
-2.03 \\
834 \\
0.80\end{array}$ & $\begin{array}{c}4.6 \%^{* * *} \\
2.92 \\
785 \\
0.82\end{array}$ \\
\hline Bull & $\begin{array}{l}\text { Alpha } \\
\text { t-statistic } \\
\text { Observations } \\
\text { Adj. R-squared }\end{array}$ & $\begin{array}{c}-0.1 \% \\
-0.22 \\
5,559 \\
0.82\end{array}$ & $\begin{array}{c}-2.6 \% \text { \%** } \\
-7.82 \\
2,672 \\
0.88\end{array}$ & $\begin{array}{c}-2.1 \% \text { *** } \\
-3.07 \\
1,251 \\
0.77\end{array}$ & $\begin{array}{c}2.6 \% \text { \%** } \\
4.13 \\
1,636 \\
0.80\end{array}$ \\
\hline
\end{tabular}

Table 10, Panel 1 shows the estimation of the performance of the groups of all active funds, of all active SPI-funds, of all active SMI-funds, and of all active SMC-funds (Small\&Mid-Cap-funds) compared to their corresponding benchmark index (benchmark portfolio). The performance is measured by the annualized alpha from panel regressions of the Switzerland-specific Carhart (1997) model. The risk premiums for the size, value, and momentum factors are provided by Ammann and Steiner (2008). The alphas are calculated for different time periods that are described in Table 3. In addition to the performance, the alpha's t-statistic, the number of observations, and the adjusted $\mathrm{R}$-squared of the regressions are shown. The asterisks indicate significance at the $1 \%$-level (***), $5 \%$-level $(* *)$, and $10 \%$-level $(*)$. 


\section{Table 10, Panel 2: Differences of Annualized Performances of Various Subgroups and Subperiods of Active Funds}

\begin{tabular}{|c|c|c|c|c|}
\hline \multirow{2}{*}{ Subperiod } & & \multicolumn{3}{|c|}{ Compared Subgroups } \\
\hline & & $\begin{array}{l}\text { SPI vs. SMI } \\
\text { funds }\end{array}$ & $\begin{array}{l}\text { SPI vs. SMC } \\
\text { funds }\end{array}$ & $\begin{array}{l}\text { SMI vs. SMC } \\
\text { funds }\end{array}$ \\
\hline Whole period & $\begin{array}{l}\text { Alpha difference } \\
\text { t-statistic }\end{array}$ & $\begin{array}{l}0.6 \% \\
1.19\end{array}$ & $\begin{array}{l}-4.0 \% \%^{* * *} \\
-7.55\end{array}$ & $\begin{array}{l}-4.6 \% \%^{* * *} \\
-6.07\end{array}$ \\
\hline Early & $\begin{array}{l}\text { Alpha difference } \\
\text { t-statistic }\end{array}$ & $\begin{array}{l}-0.9 \% \\
-0.80\end{array}$ & $\begin{array}{l}-3.0 \% \text { *** } \\
-2.77\end{array}$ & $\begin{array}{l}-2.1 \% \\
-1.28\end{array}$ \\
\hline Late & $\begin{array}{l}\text { Alpha difference } \\
\text { t-statistic }\end{array}$ & $\begin{array}{l}1.3 \%^{* *} \\
2.11\end{array}$ & $\begin{array}{l}-5.3 \% \%^{* * *} \\
-8.60\end{array}$ & $\begin{array}{l}-6.7 \% \text { \%** } \\
-7.61\end{array}$ \\
\hline Bear & $\begin{array}{l}\text { Alpha difference } \\
\text { t-statistic }\end{array}$ & $\begin{array}{l}2.0 \% \\
1.45\end{array}$ & $\begin{array}{l}-5.3 \% \%^{* * *} \\
-3.41\end{array}$ & $\begin{array}{l}-7.3 \% \%^{* * *} \\
-3.56\end{array}$ \\
\hline Bull & $\begin{array}{l}\text { Alpha difference } \\
\text { t-statistic }\end{array}$ & $\begin{array}{l}-0.5 \% \\
-0.72\end{array}$ & $\begin{array}{l}-5.2 \% \text { *** } \\
-7.98\end{array}$ & $\begin{array}{l}-4.7 \% \text { \%** } \\
-5.02\end{array}$ \\
\hline $\begin{array}{l}\text { Compared } \\
\text { Subperiods }\end{array}$ & & $\begin{array}{c}\text { Active } \\
\text { SPI-funds }\end{array}$ & $\begin{array}{l}\text { Subgroups } \\
\text { Active } \\
\text { SMI-funds }\end{array}$ & $\begin{array}{c}\text { Active } \\
\text { SMC-funds }\end{array}$ \\
\hline Early vs. late & $\begin{array}{l}\text { Alpha difference } \\
\text { t-statistic }\end{array}$ & $\begin{array}{l}2.1 \%^{* * *} \\
3.51\end{array}$ & $\begin{array}{l}4.3 \%^{* * *} \\
3.18\end{array}$ & $\begin{array}{l}-0.3 \% \\
-0.24\end{array}$ \\
\hline Bear vs. bull & $\begin{array}{l}\text { Alpha difference } \\
\text { t-statistic }\end{array}$ & $\begin{array}{l}1.9 \% \text { *** } \\
2.76\end{array}$ & $\begin{array}{l}-0.6 \% \\
-0.42\end{array}$ & $\begin{array}{l}2.0 \% \\
1.40\end{array}$ \\
\hline
\end{tabular}

Table 10, Panel 2 shows the estimation of the differences of the performances of the subgroups of active funds from Table 10, Panel 1. The alpha in Panel 1 is measured by the annualized alpha from panel regressions of the Switzerland-specific Carhart (1997) model. This Panel shows the differences of the alphas between different subgroups and time periods as well as the significance of these differences, tested by means of a t-test. The asterisks indicate significance at the $1 \%$-level $(* *), 5 \%$-level $(* *)$, and $10 \%$-level $(*)$. 
Table 11: Annualized Performance of Active Institutional and Retail Funds Compared to Their Benchmark Index

\begin{tabular}{|c|c|c|c|c|c|}
\hline \multirow[b]{2}{*}{ Subperiod } & \multicolumn{5}{|c|}{ Subgroup } \\
\hline & & $\begin{array}{l}\text { All active } \\
\text { funds }\end{array}$ & $\begin{array}{l}\text { Active insti- } \\
\text { tutional funds }\end{array}$ & $\begin{array}{l}\text { Active retail } \\
\text { funds }\end{array}$ & $\begin{array}{l}\text { alphas (inst. } \\
\text { vs. retail) }\end{array}$ \\
\hline \multirow{4}{*}{ Whole period } & Alpha & $-0.4 \% *$ & $0.4 \%$ & $-0.6 \%$ ** & $1.0 \%$ \\
\hline & t-statistic & -1.77 & 0.62 & -2.23 & 1.50 \\
\hline & Observations & 12,218 & 1,917 & 10,301 & - \\
\hline & Adj. R-squared & 0.85 & 0.82 & 0.85 & - \\
\hline \multirow{4}{*}{ Early } & Alpha & $0.2 \%$ & $0.8 \%$ & $0.1 \%$ & $0.7 \%$ \\
\hline & t-statistic & 0.32 & 0.42 & 0.15 & 0.45 \\
\hline & Observations & 3,068 & 309 & 2,759 & - \\
\hline & Adj. R-squared & 0.85 & 0.77 & 0.86 & - \\
\hline \multirow{4}{*}{ Late } & Alpha & $-0.5 \% *$ & $0.4 \%$ & $-0.8 \%^{* *}$ & $1.2 \%$ \\
\hline & t-statistic & -1.91 & 0.61 & -2.48 & 1.62 \\
\hline & Observations & 9,150 & 1,608 & 7,542 & - \\
\hline & Adj. R-squared & 0.84 & 0.83 & 0.85 & - \\
\hline \multirow{4}{*}{ Bear } & Alpha & $0.5 \%$ & $1.2 \%$ & $0.3 \%$ & $0.8 \%$ \\
\hline & t-statistic & 0.69 & 0.61 & 0.46 & 0.46 \\
\hline & Observations & 2,982 & 481 & 2,501 & - \\
\hline & Adj. R-squared & 0.82 & 0.80 & 0.83 & - \\
\hline \multirow{4}{*}{ Bull } & Alpha & $-0.1 \%$ & $2.4 \% \%^{* * *}$ & $-0.7 \% * *$ & $3.0 \%$ *** \\
\hline & t-statistic & -0.22 & 3.49 & -2.09 & 4.05 \\
\hline & Observations & 5,559 & 1,037 & 4,522 & - \\
\hline & Adj. R-squared & 0.82 & 0.82 & 0.82 & - \\
\hline
\end{tabular}

Table 11 shows the estimation of the performance of the groups of all active funds, of all active institutional funds, and of all active retail funds compared to their corresponding benchmark index (benchmark portfolio). The performance is measured by the annualized alpha from panel regressions of the Switzerland-specific Carhart (1997) model. The risk premiums for the size, value, and momentum factors are provided by Ammann and Steiner (2008). The alphas are calculated for different time periods that are described in Table 3. In addition to the performance, the alpha's $\mathrm{t}$-statistic, the number of observations, and the adjusted R-squared of the regressions are shown. The last column of the table shows the differences of the alphas between institutional and retail funds, testing the significance of these differences by means of a t-test. The asterisks indicate significance at the $1 \%$-level $\left({ }^{* *}\right), 5 \%$-level $\left({ }^{* *}\right)$, and $10 \%$-level $\left({ }^{*}\right)$. 


\subsection{Single Funds vs. Index}

This section analyses the performance of passive and active funds in comparison to theoretical indices, by providing the distribution of the alphas of the funds. Table 12 shows the alphas of a comparison of the funds to their corresponding benchmark index. Table 13 presents the distribution of the corresponding factor loadings.

As expected, Table 12 shows that the weighted mean and the median of the distribution of the alphas are negative. The weighted mean is $-0.26 \%$ p.a., which is close to the alpha of the panel regression of $-0.4 \%$ p.a. ${ }^{12} 47$ or $29.4 \%$ of the 160 funds have a positive alpha, 113 a negative alpha. This percentage is slightly higher for active than for passive funds: from all active funds, $30.5 \%$ of the alphas are positive, whereas $21.1 \%$ of the alphas of the passive funds are positive. If the probability to beat the index would be the measure, still no clear statement on the superiority of active or passive investing would be possible. Of all institutional funds, 37.5\% have positive alphas; of all retail funds, $26.7 \%$ have positive alphas. Finally, only two out of the 160 funds have a significantly positive alpha, whereas 24 or $15.0 \%$ of the alphas are significantly negative. In sum, Table 12 confirms earlier findings: Compared to hypothetical indices, the average alpha of the active and passive funds is negative. Additionally, there is still no clear picture whether active or passive funds perform better.

Table 13 confirms earlier findings as well. As in Table 5, the funds show a positive average factor loading for the size and the value factor, whereas the average factor loading of the momentum factor is negative. This confirms the preferences of Swiss equity fund managers to overweight small-cap, value, and lowmomentum stocks in comparison to their benchmark.

In sum, the first part - comparing active and passive funds to indices - provides six key findings: First, active and passive funds significantly underperform indices on an aggregated basis. However, the subgroup of the active Small\&MidCap- funds is the exception from this result. Second, no statement about the superiority of active or passive investing is possible. Third, active funds perform better in the "Early" than in the "Late" time period, which could be due to increased market efficiency. Passive funds, however, show stable performance during the "Early" and the "Late" time period. Fourth, there is no robust structure with respect to the differential between the performance during the "Bull" and the "Bear" period. Although, in the aggregated sample, it seems that the findings of Costa, JАков, and Porter (2006) are confirmed, further analysis showed that

12 See Table 6, all funds, whole period. 


\section{Table 12: Annualized Performance of All Single Funds Compared to Their Benchmark Index}

\section{Panel 1: Describtive Statistics}

Distribution of alphas (annualized)

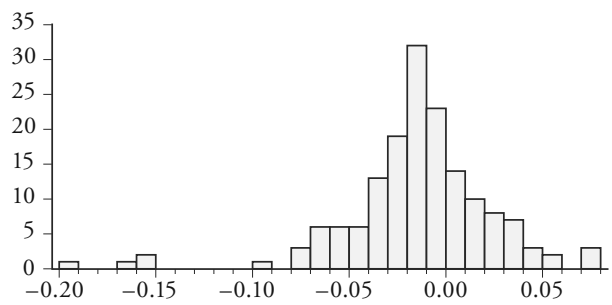

\begin{tabular}{lr}
\multicolumn{2}{l}{ Key ratios (annualized) } \\
\hline W. mean & $-0.26 \%$ \\
Median & $-1.28 \%$ \\
Std. dev. & $3.91 \%$ \\
No. of funds & 160
\end{tabular}

Panel 2: Sign and Significance of Alphas for Different Subgroups

\begin{tabular}{llrcc}
\hline & & All funds & Active funds & Passive funds \\
\hline \multirow{4}{*}{ All funds } & Number $\alpha+$ & 47 & 43 & 4 \\
& Number $\alpha-$ & 113 & 98 & 15 \\
& Number sign. $\alpha+$ & 2 & 2 & 0 \\
& Number sign. $\alpha-$ & 24 & 20 & 4 \\
\multirow{5}{*}{ All institutional funds } & Number $\alpha+$ & 15 & 13 & 2 \\
& Number $\alpha-$ & 25 & 19 & 6 \\
& Number sign. $\alpha+$ & 2 & 2 & 0 \\
& Number sign. $\alpha-$ & 5 & 3 & 2 \\
\multirow{5}{*}{ All retail funds } & Number $\alpha+$ & 32 & 30 & 2 \\
& Number $\alpha-$ & 88 & 79 & 9 \\
& Number sign. $\alpha+$ & 0 & 0 & 0 \\
& Number sign. $\alpha-$ & 19 & 17 & 2 \\
\hline
\end{tabular}

Table 12 shows the results of the estimation of the performance of all single funds compared to their corresponding benchmark index (benchmark portfolio). The performance is measured for each fund by the annualized alpha from regressions of the Switzerland-specific Carhart (1997) model. The risk premiums for the size, value, and momentum factors are provided by Ammann and Steiner (2008). Panel 1 presents the describtive statistics of the sample of the 160 alphas (Graph, Weighted Mean (with no. of observations), Median, Standard deviation, number of funds). Panel 2 shows the number of positive (Number $\alpha+$ ), negative (Number $\alpha-$ ), significantly positive (Number sign. $\alpha+$ ), and significantly negative (Number sign. $\alpha-$ ) alphas for all funds as well as for the subgroups of the active, passive, institutional, and retail funds. Significance is tested at the $5 \%$-level. 
Table 13: Distribution of the Factor Loadings of All Single Funds

Panel 1: Market- $\beta$

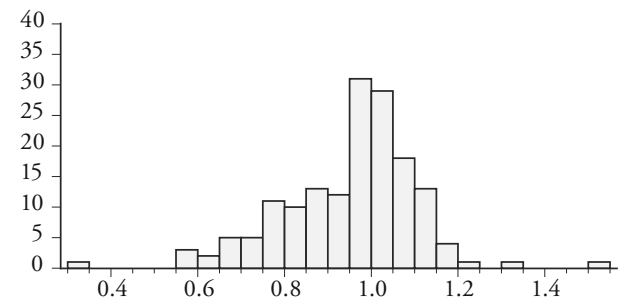

$\begin{array}{lr}\text { W. mean } & 0.96 \\ \text { Median } & 0.99 \\ \text { Funds } & 160\end{array}$

Panel 2: Size- $\beta$

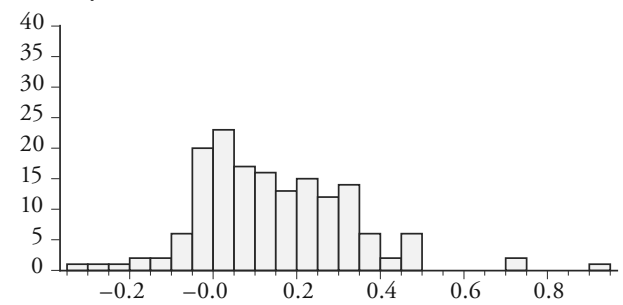

$\begin{array}{lr}\text { W. mean } & 0.15 \\ \text { Median } & 0.12 \\ \text { Funds } & 160\end{array}$

Panel 3: Value- $\beta$

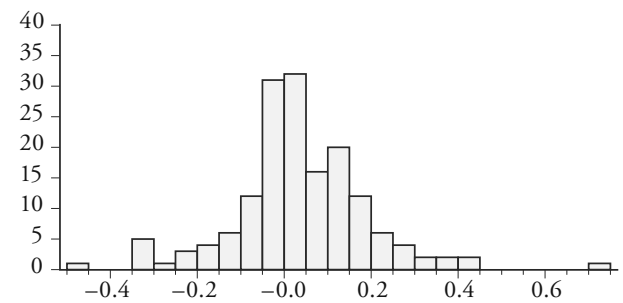

$\begin{array}{lr}\text { W. mean } & 0.04 \\ \text { Median } & 0.02 \\ \text { Funds } & 160\end{array}$

Panel 4: Momentum- $\beta$

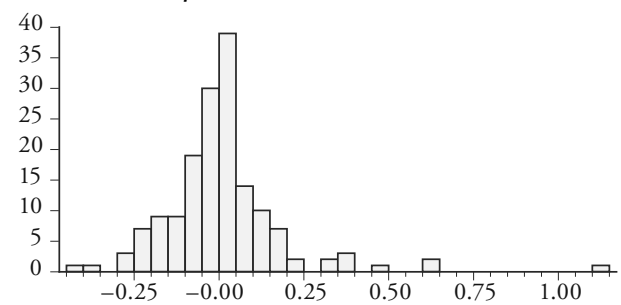
W. mean $\quad-0.03$
Median $\quad 0.00$
Funds 160

Table 13 shows the market, size, value, and momentum factor loadings of the estimation of the performance of all single funds compared to their corresponding benchmark index (benchmark portfolio). The performance and the factor loadings are estimated by means of the Switzerlandspecific Carhart (1997) model. The risk premiums for the size, value, and momentum factors are provided by Ammann and Steiner (2008). The Panels present the describtive statistics for the four factor loadings from the regressions of the 160 funds (Graph, Weighted Mean (with no. of observations), Median, number of funds). 
this result is not robust, but sensitive to the choice of the subgroup. ${ }^{13}$ Fifth, the factor loadings show that the average manager of an active Swiss equity fund overweights small-cap, value, and low-momentum stocks in comparison to the benchmark. Sixth, all our prior findings suggest that institutional funds perform better than retail funds.

\subsection{Active Funds vs. Passive Funds}

A fair judgement on the performance of active funds is only possible if they are compared directly to passive investment funds. Passive investment funds are investable instruments after costs, whereas indices are hypothetical, cost-free constructs. For that reason, this and the following section directly compare active to passive funds. The reader has to keep in mind that the comparability of the following results with the previous findings is limited. Up to now, active and passive funds had the same reference (their corresponding index), whereas in the following parts, active and passive funds will be directly compared to each other. Therefore, various characteristics of active and passive funds will be mixed. ${ }^{14}$

Table 14 starts with the evaluation of all active funds, all active SPI-funds, all active SMI-funds, and all active Small\&Mid-Cap-funds, compared to the corresponding set of passive funds as benchmark portfolios. Active SPI-funds are compared to the passive SPI-funds, active SMI-funds to the passive SMI-funds, and active SMC-funds to the passive SMC-fund. The aggregated sample of all active funds underperforms the corresponding passive funds by a highly significant $-1.1 \%$ p.a. Active SPI- and SMI-funds both underperform passive funds by a highly significant $-1.4 \%$ p.a. and $-1.9 \%$ p.a. respectively. By contrast, the active Small\&Mid-Cap-funds perform well. The alpha in comparison to the passive fund is positive and highly significant. However, as there is only one passive fund with just 27 observations, these results for the Small\&Mid-Cap-funds have to be interpreted with care. This limited sample size imposes considerable restrictions on the informative value of the comparison of active to passive Small\&Mid-Cap-

13 Costa, Јаков, and Porter (2006) find that US equity funds perform better in bear-markets than in bull-markets.

14 For example, in the next sections the difference of the "Early" to the "Late" and of the "Bear" to the "Bull" period is a result of the above differences for active and passive funds. If both active and passive funds perform better in "Bear" than in "Bull" markets when comparing them to their corresponding indices, the direct comparison of active and passive funds could show no effect as the two effects compensate each other. 
funds. For that reason, we continue the comparison of active to passive funds with a focus on the SPI- and SMI-funds.

For different subperiods, we find again that active SPI- and SMI-funds performed significantly better in the "Early" than in the "Late" time period, perhaps indicating increased market efficiency in the "Late" period. The performance in bull- and bear-markets is mixed once more.

One result from Table 14 requires further explanation. In Table 6 , active funds had a smaller underperformance compared to the corresponding indices $(-0.4 \%$ p.a.) than passive funds ( $-0.8 \%$ p.a.). It therefore seems surprising that the direct comparison of active to passive funds leads to a highly significant underperformance of the active funds of $-1.1 \%$ p.a. Intuitively, we would expect that the underperformance decreases when comparing active funds to passive funds instead of comparing them to an index. However, this result has a good reason: When changing from indices to passive funds as benchmark portfolios, the number of observations decreases as we have fewer observations for passive funds than for indices. Appendix 1 shows in detail that this shrinkage of observations leads to a decline of the performance, overcompensating the observed and expected increase of the alpha from the isolated change from indices to passive funds. The result in Table 14 is therefore consistent with the result from Table 6.

Table 15 compares active institutional and retail funds to the corresponding passive funds. We find that active institutional funds underperform passive funds by a statistically not significant $-0.1 \%$ p.a., whereas active retail funds underperform passive funds by a highly significant $-1.2 \%$ p.a. Further, the alpha of the active institutional funds is higher than the alpha of the active retail funds at a level of significance of $10 \%$. 
Table 14: Annualized Performance of Active, Benchmark-Grouped Funds Compared to the Benchmark Portfolio of all Corresponding Passive Funds

\begin{tabular}{|c|c|c|c|c|c|}
\hline \multirow[b]{3}{*}{ Subperiod } & \multirow[b]{3}{*}{$\begin{array}{l}\text { Benchmark } \\
\text { portfolio }\end{array}$} & \multicolumn{4}{|c|}{ Subgroup } \\
\hline & & $\begin{array}{l}\text { All active } \\
\text { funds }\end{array}$ & \multirow{2}{*}{$\begin{array}{l}\text { Active } \\
\text { SPI-funds } \\
\text { Passive } \\
\text { SPI-funds }\end{array}$} & \multirow{2}{*}{$\begin{array}{c}\text { Active } \\
\text { SMI-funds } \\
\text { Passive } \\
\text { SMI-funds }\end{array}$} & \multirow{2}{*}{$\begin{array}{c}\text { Active } \\
\text { SMC-funds } \\
\text { Passive } \\
\text { SMIM-funds }\end{array}$} \\
\hline & & $\begin{array}{l}\text { Corresponding } \\
\text { passive funds }\end{array}$ & & & \\
\hline \multirow{4}{*}{ Whole period } & Alpha & $-1.1 \%{ }^{* * *}$ & $-1.4 \%$ *** & $-1.9 \%$ *** & $4.4 \%^{* * *}$ \\
\hline & t-statistic & -4.76 & -5.44 & -3.81 & 6.23 \\
\hline & Observations & 9,878 & 6,019 & 2,839 & 1,020 \\
\hline & Adj. R-squared & 0.88 & 0.90 & 0.85 & 0.83 \\
\hline \multirow{4}{*}{ Early } & Alpha & $0.2 \%$ & $-0.2 \%$ & $0.9 \%$ & n.a. \\
\hline & t-statistic & 0.43 & -0.30 & 0.86 & - \\
\hline & Observations & 2,305 & 1,705 & 600 & - \\
\hline & Adj. R-squared & 0.90 & 0.91 & 0.88 & - \\
\hline \multirow{3}{*}{ Late } & $\begin{array}{l}\text { Alpha } \\
\text { t-statistic }\end{array}$ & $\begin{array}{l}-1.6 \% \%^{* * *} \\
-6.13\end{array}$ & $\begin{array}{l}-2.5 \%^{* * *} \\
-8.31\end{array}$ & $\begin{array}{l}-3.5 \%^{* * *} \\
-6.07\end{array}$ & $\begin{array}{l}4.4 \%^{* * *} \\
6.23\end{array}$ \\
\hline & Observations & 7,573 & 4,314 & 2,239 & 1,020 \\
\hline & Adj. R-squared & 0.87 & 0.90 & 0.83 & 0.83 \\
\hline \multirow{4}{*}{ Bear } & Alpha & $-1.5 \% * *$ & $-0.8 \%$ & $-2.6 \% * *$ & n.a. \\
\hline & t-statistic & -2.32 & -1.10 & -2.18 & - \\
\hline & Observations & 2,197 & 1,363 & 834 & - \\
\hline & Adj. R-squared & 0.86 & 0.89 & 0.83 & - \\
\hline \multirow{4}{*}{ Bull } & Alpha & $-0.3 \%$ & $-2.0 \% * * *$ & $-1.3 \% * *$ & $4.4 \% * * *$ \\
\hline & t-statistic & 1.19 & -6.09 & -1.98 & 6.23 \\
\hline & Observations & 4,943 & 2,672 & 1,251 & 1,020 \\
\hline & Adj. R-squared & 0.83 & 0.88 & 0.79 & 0.83 \\
\hline
\end{tabular}

Table 14 shows the estimation of the performance of the groups of all active funds, of all active SPI-funds, of all active SMI-funds, and of all active SMC-funds (Small\&Mid-Cap-funds) compared to all corresponding passive funds (equally-weighted benchmark portfolio). All active funds are compared to a benchmark portfolio of all corresponding passive funds, active SPI-funds to a benchmark portfolio of passive SPI-funds, active SMI-funds to a benchmark portfolio of passive SMI-funds, and active SMC-funds to a passive SMIM-fund. The performance is measured by the annualized alpha from panel regressions of the Switzerland-specific Carhart (1997) model. The risk premiums for the size, value, and momentum factors are provided by Ammann and Steiner (2008). The alphas are calculated for different time periods that are described in Table 3. In addition to the performance, the alpha's t-statistic, the number of observations, and the adjusted $\mathrm{R}$-squared of the regressions are shown. The asterisks indicate significance at the $1 \%$-level $\left({ }^{* *}\right)$, $5 \%$-level $(* *)$, and $10 \%$-level $(*)$.

$\ddagger$ As there is only one passive fund with just 27 observations, these results for the SMC-funds have to be interpreted with care. 
Table 15: Annualized Performance of Active Institutional and Retail Funds Compared to the Corresponding Benchmark Portfolio of Passive Funds

\begin{tabular}{|c|c|c|c|c|c|}
\hline \multirow[b]{3}{*}{ Subperiod } & \multicolumn{5}{|c|}{ Subgroup } \\
\hline & & $\begin{array}{l}\text { All active } \\
\text { funds }\end{array}$ & $\begin{array}{c}\text { Active } \\
\text { institutional } \\
\text { funds }\end{array}$ & $\begin{array}{l}\text { Active retail } \\
\text { funds }\end{array}$ & $\begin{array}{l}\text { difference of } \\
\text { alphas } \\
\text { (inst. vs. retail) }\end{array}$ \\
\hline & $\begin{array}{l}\text { Benchmark } \\
\text { portfolio }\end{array}$ & $\begin{array}{l}\text { Corresponding } \\
\text { passive Funds }\end{array}$ & $\begin{array}{l}\text { Corresponding } \\
\text { passive Funds }\end{array}$ & $\begin{array}{l}\text { Corresponding } \\
\text { passive Funds }\end{array}$ & \\
\hline \multirow{4}{*}{ Whole period } & Alpha & $-1.1 \%$ *** & $-0.1 \%$ & $-1.2 \%^{* * *}$ & $1.1 \% *$ \\
\hline & t-statistic & -4.76 & -0.11 & -5.10 & 1.73 \\
\hline & Observations & 9,878 & 1,405 & 8,473 & - \\
\hline & Adj. R-squared & 0.88 & 0.82 & 0.89 & - \\
\hline \multirow{4}{*}{ Early } & Alpha & $0.2 \%$ & $0.7 \%$ & $0.2 \%$ & n.a. \\
\hline & t-statistic & 0.43 & 0.30 & 0.36 & - \\
\hline & Observations & 2,305 & 201 & 2,104 & - \\
\hline & Adj. R-squared & 0.90 & 0.72 & 0.91 & - \\
\hline \multirow{4}{*}{ Late } & Alpha & $-1.6 \% * * *$ & $-0.5 \%$ & $-1.9 \% * * *$ & $1.4 \% *$ \\
\hline & t-statistic & -6.13 & -0.64 & -6.58 & 1.93 \\
\hline & Observations & 7,573 & 1,204 & 6,369 & - \\
\hline & Adj. R-squared & 0.87 & 0.84 & 0.87 & - \\
\hline \multirow{4}{*}{ Bear } & Alpha & $-1.5 \% * *$ & $-2.4 \%$ & $-1.3 \%^{* *}$ & $-1.1 \%$ \\
\hline & t-statistic & -2.32 & -1.16 & -2.05 & -0.57 \\
\hline & Observations & 2,197 & 293 & 1,904 & - \\
\hline & Adj. R-squared & 0.86 & 0.82 & 0.87 & - \\
\hline \multirow{4}{*}{ Bull } & Alpha & $-0.3 \%$ & $3.2 \%^{* * *}$ & $-0.3 \%$ & $3.5 \%^{* * *}$ \\
\hline & t-statistic & -1.19 & 4.53 & -1.02 & 4.65 \\
\hline & Observations & 4,943 & 861 & 4,082 & - \\
\hline & Adj. R-squared & 0.83 & 0.82 & 0.83 & - \\
\hline
\end{tabular}

Table 15 shows the estimation of the performance of the groups of all active funds, of all active institutional funds, and of all active retail funds compared to all corresponding passive funds (equally-weighted benchmark portfolio). All active funds are compared to the benchmark portfolio of all passive funds, all active institutional funds are compared to the benchmark portfolio of all passive institutional funds, and all active retail funds are compared to the benchmark portfolio of all passive retail funds. The performance is measured by the annualized alpha from panel regressions of the Switzerland-specific Carhart (1997) model. The risk premiums for the size, value, and momentum factors are provided by Ammann and Steiner (2008). The alphas are calculated for different time periods that are described in Table 3. In addition to the performance, the alpha's $\mathrm{t}$-statistic, the number of observations, and the adjusted R-squared of the regressions are shown. The last column of the table shows the differences of the alphas between institutional and retail funds, testing the significance of these differences by means of a t-test. The asterisks indicate significance at the $1 \%$-level $\left({ }^{* *}\right)$, 5\%-level $(* *)$, and $10 \%$-level $\left({ }^{*}\right)$. 


\subsection{Active SPI- and SMI-Funds vs. Passive Funds}

Finally, in Tables 16 and 17 we look into the subgroups of the active institutional and retail SPI- and SMI-funds by comparing them to corresponding benchmark portfolios of passive funds. These final evaluations have to be interpreted with care for three reasons: First, the samples get smaller. Second, there are time periods where we have a lack of data for the active funds or the corresponding benchmark portfolio. Third, the findings are a mixture of effects resulting from the performance of active funds and of passive funds.

Tables 16 and 17 confirm that active SPI- and SMI-funds generally underperform their passive equivalents. However, theses tables show as well that the performance of institutional and retail funds depends strongly on the subgroup analysed. While active institutional SPI-funds have a performance insignificantly different from passive SPI-funds ( $-0.4 \%$ p.a.), active institutional SMI-funds underperform passive SMI-funds by a highly significant $-4.5 \%$ p.a. The picture is less differentiated for active retail SPI- and SMI-funds. Both active retail SPIand SMI-funds underperform their passive counterparts by a significant $-1.5 \%$ p.a. Within the sample of the active retail SPI-funds described in Table 16, we further tested whether the location of the fund management influences the performance of the fund. The results of this analysis indicate that there could be a small information advantage of locally managed funds, however, the difference of $0.6 \%$ p.a. is not statistically significant. The details of this analysis are not reported here, but are available from the authors on request.

In sum, the second part (Tables 14 to 17 ) - directly comparing actively managed funds to benchmark portfolios of passively managed funds - allows additional observations on the performance of actively managed Swiss equity funds. First, actively managed funds significantly underperform passively managed funds by $-1.1 \%$ p.a. on an aggregated basis. Second, this part confirms again that - on an aggregated basis - institutional Swiss equity funds perform better than retail funds. However, this result depends on the subgroup analysed: It is true for active SPI-funds, but does not hold for active SMI-funds. 


\section{Table 16: Annualized Performance of Active Institutional and Retail SPI-Funds Compared to the Benchmark Portfolio of all Passive SPI-Funds}

\begin{tabular}{|c|c|c|c|c|}
\hline \multirow[b]{3}{*}{ Subperiod } & \multirow[b]{3}{*}{$\begin{array}{l}\text { Benchmark } \\
\text { portfolio }\end{array}$} & \multicolumn{3}{|c|}{ Subgroup } \\
\hline & & $\begin{array}{l}\text { All active } \\
\text { SPI-funds }\end{array}$ & $\begin{array}{l}\text { Active institutional } \\
\text { SPI-funds }\end{array}$ & $\begin{array}{l}\text { Active retail } \\
\text { SPI-funds }\end{array}$ \\
\hline & & $\begin{array}{l}\text { Passive } \\
\text { SPI-funds }\end{array}$ & $\begin{array}{l}\text { Passive } \\
\text { SPI-funds }\end{array}$ & $\begin{array}{l}\text { Passive } \\
\text { SPI-funds }\end{array}$ \\
\hline Whole period & $\begin{array}{l}\text { Alpha } \\
\text { t-statistic } \\
\text { Observations } \\
\text { Adj. R-squared }\end{array}$ & $\begin{array}{c}-1.4 \% * * * \\
-5.44 \\
6,019 \\
0.90\end{array}$ & $\begin{array}{c}-0.4 \% \\
-0.38 \\
616 \\
0.80\end{array}$ & $\begin{array}{c}-1.5 \%^{* * *} \\
-5.95 \\
5,403 \\
0.91\end{array}$ \\
\hline Early & $\begin{array}{l}\text { Alpha } \\
\text { t-statistic } \\
\text { Observations } \\
\text { Adj. R-squared }\end{array}$ & $\begin{array}{c}-0.2 \% \\
-0.30 \\
1,705 \\
0.91\end{array}$ & $\begin{array}{c}0.6 \% \\
0.23 \\
197 \\
0.72\end{array}$ & $\begin{array}{c}-0.3 \% \\
-0.55 \\
1,508 \\
0.93\end{array}$ \\
\hline Late & $\begin{array}{l}\text { Alpha } \\
\text { t-statistic } \\
\text { Observations } \\
\text { Adj. R-squared }\end{array}$ & $\begin{array}{c}-2.5 \%^{* * *} \\
-8.31 \\
4,314 \\
0.90\end{array}$ & $\begin{array}{l}-2.5 \%^{* *} \\
-2.04 \\
419 \\
0.85\end{array}$ & $\begin{array}{c}-2.5 \% \text { *** } \\
-8.14 \\
3,895 \\
0.90\end{array}$ \\
\hline Bear & $\begin{array}{l}\text { Alpha } \\
\text { t-statistic } \\
\text { Observations } \\
\text { Adj. R-squared }\end{array}$ & $\begin{array}{c}-0.8 \% \\
-1.10 \\
1,363 \\
0.89\end{array}$ & $\begin{array}{c}-1.4 \% \\
-0.48 \\
134 \\
0.81\end{array}$ & $\begin{array}{c}-0.7 \% \\
-1.01 \\
1,229 \\
0.60\end{array}$ \\
\hline Bull & $\begin{array}{l}\text { Alpha } \\
\text { t-statistic } \\
\text { Observations } \\
\text { Adj. R-squared }\end{array}$ & $\begin{array}{c}-2.0 \% * * * \\
-6.09 \\
2,672 \\
0.88\end{array}$ & $\begin{array}{c}-1.2 \% \\
-1.21 \\
247 \\
0.90\end{array}$ & $\begin{array}{c}-2.1 \%^{* * *} \\
-6.02 \\
2,425 \\
0.88\end{array}$ \\
\hline
\end{tabular}

Table 16 shows the estimation of the performance of the groups of all active SPI-Funds, of all active institutional SPI-Funds, and of all active retail SPI-Funds compared to the passive SPIFunds (equally-weighted benchmark portfolio). The performance is measured by the annualized alpha from panel regressions of the Switzerland-specific Carhart (1997) model. The risk premiums for the size, value, and momentum factors are provided by Ammann and Steiner (2008). The alphas are calculated for different time periods that are described in Table 3. In addition to the performance, the alpha's t-statistic, the number of observations, and the adjusted R-squared of the regressions are shown. The asterisks indicate significance at the $1 \%$-level $\left(^{* * *}\right), 5 \%$-level $\left({ }^{* *}\right)$, and $10 \%$-level $(*)$. 
Table 17: Annualized Performance of Active Institutional and Retail SMI-Funds Compared to the Benchmark Portfolio of all Passive SMI-Funds

\begin{tabular}{|c|c|c|c|c|}
\hline \multirow[b]{3}{*}{ Subperiod } & \multirow[b]{3}{*}{$\begin{array}{l}\text { Benchmark } \\
\text { portfolio }\end{array}$} & \multicolumn{3}{|c|}{ Subgroup } \\
\hline & & $\begin{array}{l}\text { All active } \\
\text { SMI-funds }\end{array}$ & $\begin{array}{l}\text { Active institutional } \\
\text { SMI-funds }\end{array}$ & $\begin{array}{l}\text { Active retail } \\
\text { SMI-funds }\end{array}$ \\
\hline & & $\begin{array}{l}\text { Passive } \\
\text { SMI-funds }\end{array}$ & $\begin{array}{l}\text { Passive } \\
\text { SMI-funds }\end{array}$ & $\begin{array}{l}\text { Passive } \\
\text { SMI-funds }\end{array}$ \\
\hline Whole period & $\begin{array}{l}\text { Alpha } \\
\text { t-statistic } \\
\text { Observations } \\
\text { Adj. R-squared }\end{array}$ & $\begin{array}{c}-1.9 \% \text { *** } \\
-3.81 \\
2,839 \\
0.85\end{array}$ & $\begin{array}{l}-4.5 \%^{* * *} \\
-3.31 \\
453 \\
0.83\end{array}$ & $\begin{array}{c}-1.5 \%^{* * *} \\
-2.90 \\
2,386 \\
0.85\end{array}$ \\
\hline Early & $\begin{array}{l}\text { Alpha } \\
\text { t-statistic } \\
\text { Observations } \\
\text { Adj. R-squared }\end{array}$ & $\begin{array}{c}0.9 \% \\
0.86 \\
600 \\
0.88\end{array}$ & $\begin{array}{c}\text { n.a. } \\
- \\
- \\
-\end{array}$ & $\begin{array}{c}0.9 \% \\
0.84 \\
596 \\
0.89\end{array}$ \\
\hline Late & $\begin{array}{l}\text { Alpha } \\
\text { t-statistic } \\
\text { Observations } \\
\text { Adj. R-squared }\end{array}$ & $\begin{array}{c}-3.5 \% \text { \%** } \\
-6.07 \\
2,239 \\
0.83\end{array}$ & $\begin{array}{l}-4.5 \%^{* * *} \\
-3.31 \\
453 \\
0.83\end{array}$ & $\begin{array}{c}-3.2 \%^{* * *} \\
-5.12 \\
1,790 \\
0.84\end{array}$ \\
\hline Bear & $\begin{array}{l}\text { Alpha } \\
\text { t-statistic } \\
\text { Observations } \\
\text { Adj. R-squared }\end{array}$ & $\begin{array}{c}-2.6 \% \text { ** } \\
-2.18 \\
834 \\
0.83\end{array}$ & $\begin{array}{c}-3.5 \% \\
-1.22 \\
159 \\
0.84\end{array}$ & $\begin{array}{c}-2.5 \%^{*} \\
-1.88 \\
675 \\
0.83\end{array}$ \\
\hline Bull & $\begin{array}{l}\text { Alpha } \\
\text { t-statistic } \\
\text { Observations } \\
\text { Adj. R-squared }\end{array}$ & $\begin{array}{c}-1.3 \% \text { ** } \\
-1.98 \\
1,251 \\
0.79\end{array}$ & $\begin{array}{c}0.0 \% \\
-0.01 \\
278 \\
0.72\end{array}$ & $\begin{array}{l}-1.6 \%^{* *} \\
-2.30 \\
973 \\
0.81\end{array}$ \\
\hline
\end{tabular}

Table 17 shows the estimation of the performance of the groups of all active SMI-Funds, of all active institutional SMI-Funds, and of all active retail SMI-Funds compared to the passive SMIfunds (equally-weighted benchmark portfolio). The performance is measured by the annualized alpha from panel regressions of the Switzerland-specific Carhart (1997) model. The risk premiums for the size, value, and momentum factors are provided by Ammann and Steiner (2008). The alphas are calculated for different time periods that are described in Table 3. In addition to the performance, the alpha's t-statistic, the number of observations, and the adjusted R-squared of the regressions are shown. The asterisks indicate significance at the $1 \%$-level $\left({ }^{* *}\right), 5 \%$-level $\left({ }^{* *}\right)$, and $10 \%$-level $(*)$. 


\section{Conclusion}

This study analyses the risk-adjusted performance of 160 actively and passively managed mutual funds investing in Swiss stocks between 1989 and 2007. Our contribution to the existing literature is threefold: First, we substantially extend the scarce research on the performance of Swiss equity funds by applying a more recent performance measurement methodology, by analysing a much larger sample with a reduced survivorship bias, by analysing factor loadings and by investigating the performance and the robustness of the results in different subgroups and subperiods. Second, we directly compare actively and passively managed Swiss equity funds on the basis of a Switzerland-specific Carhart model. Third, we analyse the performance of passive Swiss equity funds. To the best of our knowledge, we are the first to compare the performance of active Swiss equity funds not only to a theoretical index, but also to passive index funds, to apply the Carhart methodology to compare active and passive funds, and to analyse the performance of passive Swiss equity funds.

We find that, on average, active and passive Swiss equity funds significantly underperform their benchmark indices. By analysing various subgroups, we find that both active SPI- and SMI-funds significantly underperform their corresponding indices by $2.0 \%$ p.a. and $2.6 \%$ p.a. respectively, while passive SPI- and SMIfunds significantly underperform by $0.5 \%$ p.a. and $1 \%$ p.a. respectively. Active Small\&Mid-Cap-funds, however, exhibit a significantly positive risk-adjusted performance of $2.0 \%$ p.a. The superior performance of Small\&Mid-Cap-funds may be an indication of lower market efficiency in this segment. Consequently, we conclude that in the Swiss stock market actively managing small- and midcap investments may be worthwhile, whereas high market efficiency favours passive investments in the large-cap segment.

Further, the factor loadings of the Switzerland-specific Carhart model show that the average manager of an active Swiss equity fund systematically overweights small-cap, value, and low-momentum stocks in comparison to the benchmark.

When directly comparing active to passive Swiss equity funds, we find a significant underperformance of the active funds of $-1.1 \%$ p.a. on an aggregated basis. The results vary for different subgroups, confirming the findings resulting from the comparison to indices. While active institutional funds can almost keep up with the performance of passive funds, active retail funds cannot and drive the substantial underperformance observed for active funds. Furthermore, the results of earlier studies finding that active equity mutual funds perform better in bear- than in bull-markets are not confirmed. Our analysis reveals that the spread between bulland bear-market-alphas is sensitive to the subgroup and subperiod analysed. 
Finally, we analyse different subperiods. We find that active funds perform better before the millennium than thereafter, while passive funds show no respective performance difference. This robust result supports the hypothesis of ongoing efficiency increases in the stock market, making active fund management more challenging from a performance perspective.

\section{Appendix 1}

Table A1 shows that the aggregated performance of all active funds in Tables 6 , 10, and 11 (indices as benchmark portfolios, column 1 in Table A1) is consistent with the performance of all active funds in Tables 14 and 15 (passive funds as benchmark portfolios, column 3 in Table A1). Table A1 demonstrates that by decomposing the change of the benchmark portfolio (from corresponding indices to corresponding passive funds) into the two comprised steps, both influencing the change of the alpha.

The first step (from column 1 to 2 in Table A1) is the reduction of observations, resulting from lower data availability for passive funds than for indices. This effect has been isolated in the first step through changing the sample size only, but not the benchmark portfolio. As Table A1 shows, this effect further decreases the alpha. This is due to the fact that mainly the observations from the SMC-funds and the Early time period, both comparably good performing subgroups, are affected by this data shrinkage.

The second step (from column 2 to 3 in Table A1) is the change of the benchmark portfolio from corresponding indices to corresponding passive funds (with fixed observations). As expected, Table A1 shows that this effect decreases the underperformance.

By merging steps one and two - both causing explainable changes of the alphas - there results an intuitively unexpected, but well explainable decrease of the alpha (from column 1 to 3 in Table A1).

Our further analysis not reported here showed that the same effect is causing the decrease of the aggregated alpha of all active retail funds. Changing the benchmark portfolio from the corresponding indices (Table 11) to the corresponding passive funds (Table 15), the decrease of the alpha resulting from the reduction of observations (step 1) overcompensates the increase of the alpha from the isolated change of the benchmark portfolio (step 2). 
Table A1: Annualized Performance of all Active Funds

Compared to the Corresponding Indices and Passive Funds, Dependent on Data Availability for Indices and Passive Funds

\begin{tabular}{|c|c|c|c|c|}
\hline \multirow[b]{4}{*}{ Subperiod } & \multirow{4}{*}{$\begin{array}{l}\text { Benchmark } \\
\text { portfolio } \\
\text { Observations } \\
\text { included }\end{array}$} & \multicolumn{3}{|c|}{ Subgroup } \\
\hline & & $\stackrel{(1)}{\text { All }}$ & $\stackrel{(2)}{(2)}$ & (3) \\
\hline & & $\begin{array}{l}\text { Corresponding } \\
\text { indices }\end{array}$ & $\begin{array}{l}\text { Corresponding } \\
\text { indices }\end{array}$ & $\begin{array}{l}\text { Corresponding } \\
\text { passive funds }\end{array}$ \\
\hline & & All observations & \multicolumn{2}{|c|}{$\begin{array}{l}\text { Observations with available data } \\
\text { for index and passive funds }\end{array}$} \\
\hline \multirow{4}{*}{ Whole period } & Alpha & $-0.4 \% *$ & $-1.8 \% \%^{* * *}$ & $-1.1 \% \%^{* * *}$ \\
\hline & t-statistic & -1.77 & -7.63 & -4.76 \\
\hline & Observations & 12,218 & 9,878 & 9,878 \\
\hline & Adj. R-squared & 0.85 & 0.87 & 0.88 \\
\hline \multirow{4}{*}{ Early } & Alpha & $0.2 \%$ & $-0.5 \%$ & $0.2 \%$ \\
\hline & t-statistic & 0.32 & -1.09 & 0.43 \\
\hline & Observations & 3,068 & 2,305 & 2,305 \\
\hline & Adj. R-squared & 0.85 & 0.89 & 0.90 \\
\hline \multirow{4}{*}{ Late } & Alpha & $-0.5 \% *$ & $-2.4 \%^{* * *}$ & $-1.6 \% * * *$ \\
\hline & t-statistic & -1.91 & -8.81 & -6.13 \\
\hline & Observations & 9,150 & 7,573 & 7,573 \\
\hline & Adj. R-squared & 0.84 & 0.86 & 0.87 \\
\hline \multirow{4}{*}{ Bear } & Alpha & $0.5 \%$ & $-1.4 \% * *$ & $-1.5 \% \%^{* *}$ \\
\hline & t-statistic & 0.69 & -2.08 & -2.32 \\
\hline & Observations & 2,982 & 2,197 & 2,197 \\
\hline & Adj. R-squared & 0.82 & 0.84 & 0.86 \\
\hline \multirow{4}{*}{ Bull } & Alpha & $-0.1 \%$ & $-0.8 \% * * *$ & $-0.3 \%$ \\
\hline & t-statistic & -0.22 & -2.62 & -1.19 \\
\hline & Observations & 5,559 & 4,943 & 4,943 \\
\hline & Adj. R-squared & 0.82 & 0.83 & 0.83 \\
\hline
\end{tabular}

Table A1 shows the estimation of the performance of all active funds compared to different benchmark portfolios. The first column shows the results of all active funds being compared to the corresponding indices (benchmark portfolios). In the second column, the data for the indices (benchmark portfolios) are limited to the data points where data on passive funds are available. The third column finally shows the results of all active funds being compared to the corresponding passive funds (benchmark portfolios). The performance is measured by the annualized alpha from panel regressions of the Switzerland-specific Carhart (1997) model. The risk premiums for the size, value and momentum factors are provided by Ammann and Steiner (2008). The alphas are calculated for different time periods that are described in Table 4. In addition to the performance, the alpha's $\mathrm{t}$-statistic, the number of observations and the adjusted R-squared of the regressions are shown. The asterisks indicate significance at the $1 \%$-level $\left({ }^{* *}\right), 5 \%$-level $\left({ }^{* *}\right)$, and $10 \%$-level $\left(^{*}\right)$. 


\section{References}

Ammann, Manuel, Corinne Häller and Rico von Wyss (2002), „Performance Schweizerischer Anlagestiftungen“, Financial Markets and Portfolio Management, 16, pp.446-466.

Ammann, Manuel and Michael Steiner (2008), "Risk Factors for the Swiss Stock Market", Swiss Journal of Economics and Statistics, 144, pp. 1-35.

Avramov, Doron and Russ Wermers (2006), "Investing in Mutual Funds when Returns are Predictable", Journal of Financial Economics, 81, pp. 339-377.

Bams, Dennis and Roger Otten (2002), "European Mutual Fund Performance", European Financial Management, 8, pp. 75-101.

Berk, Jonathan B. (2005), "Five Myths of Active Portfolio Management", The Journal of Portfolio Mangement, 31, pp. 27-31.

Bogle, John C. (1998), “The Implications of Style Analysis for Mutual Fund Performance Evaluation", The Journal of Portfolio Management, 24, pp. 34-42.

Bogle, John C. (2002), "An Index Fund Fundamentalist", The Journal of Portfolio Management, 28, pp. 31-38.

Bogle, John C. (2005), "The Mutual Fund Industry 60 Years Later: For Better or Worse?", Financial Analysts Journal, 61, pp. 15-24.

Brown, Stephen J. and William N. Goetzmann (1995), "Performance Persistence", The Journal of Finance, 50, pp. 679-698.

Carhart, Mark M. (1997), "On Persistence in Mutual Fund Performance", The Journal of Finance, 52, pp. 57-82.

Carhart, Mark M., Jennifer N. Carpenter, Anthony W. Lynch and David K. Musto (2002), "Mutual Fund Survivorship", The Review of Financial Studies, 15, pp. 1439-1463.

Costa, Bruce A., Keith Jakob and Gary E. Porter (2006), "Mutual Fund Performance and Changing Market Trends 1990-2001: Does Manager Experience Matter?", The Journal of Investing, 15, pp.79-86.

Deaves, Richard (2004), "Data-Conditioning Biases, Performance, Persistence and Flows: The Case of Canadian Equity Funds", Journal of Banking and Finance, 28, pp.673-694.

Elton, Edwin J., Martin J. Gruber and Christopher R. Blake (1996), "Survivorship Bias and Mutual Fund Performance", The Review of Financial Studies, 9, pp. 1097-1120.

Fama, Eugene F. and Kenneth R. French (1993), "Common Risk Factors in the Returns on Stocks and Bonds", Journal of Financial Economics, 33, pp.3-56.

Fortin, Rich and Stuart Michelson (2002), "Indexing Versus Active Mutual Fund Management”, Journal of Financial Planning, 15, pp. 82-94. 
Griese, Knut and Alexander Kempf (2003), „Lohnt aktives Fondsmanagement aus Anlegersicht?", Zeitschrift für Betriebswirtschaft, 73, pp. 201-224.

Grinblatt, Mark and Sheridan Titman (1989), "Mutual Fund Performance: An Analysis of Quarterly Portfolio Holdings", The Journal of Business, 62, pp. 393-416.

Gruber, Martin J. (1996), "Another Puzzle: The Growth in Actively Managed Mutual Funds", The Journal of Finance, 51, pp. 783-810.

Jensen, Michael (1968), "The Performance of Mutual Funds in the Period 1945-1964", The Journal of Finance, 23, pp. 389-416.

Kizer, Jared (2005), "Index Fundamentalism Revisited - Redux", The Journal of Portfolio Management, 31, pp. 112-119.

Lhabitant, Francois-Serge (1995), "Mutual Funds Performance: Empirical Tests on the Swiss Market", Financial Markets and Portfolio Management, 9, pp.330-351.

Lhabitant, Francois-Serge (2001), "On Swiss Timing and Selectivity: In the Quest of Alpha", Financial Markets and Portfolio Management, 15, pp. 154-172.

Lehmann, Bruce N. and David Modest (1987), "Mutual Fund Performance Evaluation: A Comparison of Benchmarks and Benchmark Comparisons", The Journal of Finance, 42, pp. 233-265.

Malkiel, Burton G. (1995), "Returns from Investing in Equity Mutual Funds 1971 to 1991", The Journal of Finance, 50, pp. 549-572.

Malkiel, Burton G. (2003), "Passive Investment Strategies and Efficient Markets", European Financial Management, 9, pp. 1-10.

Malkiel, Burton G. (2005), "Reflections on the Efficient Market Hypothesis: 30 Years Later", The Financial Review, 40, pp. 1-9.

Minor, Dylan B. (2001), "Beware of Index Fund Fundamentalists", The Journal of Portfolio Management, 27, pp.45-50.

Minor, Dylan B. (2003), "Transcending the Active/Passive Debate", The Journal of Investing, 12, pp. 74-82.

Reinker, Kenneth S. and Edward Tower (2004), "Index Fundamentalism Revisited", Journal of Portfolio Management, 30, pp. 37-50.

Von Wyss, Rico (2001), "Performance Measurement of Equity Funds - Do the SPPS Enhance Transparency?", Financial Markets and Portfolio Management, 15, pp. 173-186.

Wermers, Russ (2000), "Mutual Fund Performance: An Empirical Decomposition into Stock-Picking Talent, Style, Transaction Costs, and Expenses", The Journal of Finance, 55, pp. 1655-1703. 
Zimmermann, Heinz and Claudia Zogg-Wetter (1992), „Performance-Messung schweizerischer Aktienfonds: Markt-Timing und Selektivität", Swiss Journal of Economics and Statistics, 128, pp. 133-159.

\section{SUMMARY}

Using a Switzerland-specific Carhart model, we study the risk-adjusted performance of actively and passively managed mutual funds investing in Swiss stocks from 1989 to 2007. We also compare the performance of actively managed funds to passively managed funds instead of comparing them to a theoretical index. For a sample of 160 funds with 13,672 monthly observations we find that active as well as passive funds significantly underperform indices on an aggregated basis. However, active large-cap funds significantly underperform and active Small\&Mid-Cap-funds significantly outperform the index. Further, we find that the average manager of an active Swiss equity fund systematically overweights small-cap, value, and low-momentum stocks. When directly comparing active to passive funds, active funds significantly underperform by $-1.1 \%$ p.a. on average. While active institutional funds can almost keep up with the performance of passive funds, active retail funds cannot and drive the substantial underperformance observed for active funds. Finally, active funds perform better before the millennium than thereafter. This robust result supports the hypothesis of ongoing efficiency increases in the Swiss stock market. 